\title{
NEKE DVOJBE U PRIMJENI ZAKONA O NAKNADI ZA IMOVINU ODUZETU ZA VRIJEME JUGOSLAVENSKE KOMUNISTIČKE VLADAVINE
}

\section{- Pravna narav roka za pokretanje postupka / odnos prema Ugovoru Republike Hrvatske i Svete Stolice o gospodarskim pitanjima -}

Dr. sc. Marko Babić, sudac Ustavnog suda RH

Docent Ekonomskog fakulteta Sveučilišta u Zagrebu

Dr. sc. Eduard Kunštek, redoviti profesor

Pravni fakultet Sveučilišta u Rijeci
UDK 347.232 .1

Ur.: 10. ožujka 2016. Pr.: 29. ožujka 2016.

Izvorni znanstveni rad

\begin{abstract}
Sažetak
U radu se analizira samo dio problema koji su se pojavili u primjeni Zakona o naknadi za imovinu oduzetu za vrijeme jugoslavenske komunističke vladavine te Ugovora o gospodarskim pitanjima sklopljenog između Republike Hrvatske i Svete Stolice. Čini se da je spor o pravnoj prirodi roka za pokretanje postupka prema navedenom i drugim zakonima, barem kad je u pitanju judikatura, riješen odlukom Ustavnog suda u predmetu U-III-5694/13 od 1. ožujka 2016. To se ne može kazati za dvojbe koje postoje u svezi s primjenom tog Zakona $i$ njegovim odnosom prema Ugovoru sa Svetom Stolicom. U radu su se iznijeli $i$ analizirali suprotstavljeni argumenti za različita stajališta glede najvažnijih pitanja unutar polja primjene tih pravnih propisa, koji su jednako opravdani $i$ uvjerljivi. Stoga autori preporučuju da ugovorne strane i/ili mješovito povjerenstvo iz toga Ugovora iskoriste svoje ovlasti i urede odnose Svete Stolice i Republike Hrvatske na jasan i nedvosmislen način.
\end{abstract}

Ključne riječi: naknada za oduzetu imovinu, rok za pokretanje postupka, Sveta Stolica.

\section{UVOD}

Primjena Zakona o naknadi za imovinu oduzetu za vrijeme jugoslavenske komunističke vladavine (dalje: Zakon o naknadi ili ZON) ${ }^{1}$ izazvala je niz dvojbi

$1 \quad$ Narodne novine, 92/96., 39/99., 42/99., 92/99., 43/00., 131/00., 27/01., 65/01., 118/01., 80/02., 81/02. 
koje su još uvijek predmet brojnih rasprava u hrvatskoj doktrini i judikaturi. ${ }^{2}$ Ovaj rad predstavlja doprinos tim raspravama u svezi s dva problemska pitanja. Ona se odnose na:

- pravnu narav roka za podnošenje zahtjeva za naknadu i pravila o njegovu održanju koja bi trebalo primijeniti za slučaj da on pada u neradni dan - u svezi s čime su autori ovoga rada prethodno napisali prilog za XXI. Savjetovanje „Petar Simonetti“ (2015.), pri čemu se nisu posebno osvrnuli na pravnu narav samih rokova, već na prijepor koji postoji glede primjene pravila o njihovu održanju ${ }^{3}$ i

- učinke međunarodnih ugovora na primjenu Zakona o naknadi, a napose na onaj kojega je Republike Hrvatska sklopila sa Svetom Stolicom u svezi s gospodarskim pitanjima (dalje Ugovor o gospodarskim pitanjima ili Ugovor). ${ }^{4}$

\section{I.}

Kad je u pitanju pravna narav roka za pokretanje postupka prema ZON-u, dio judikature i doktrine zastupa stajalište prema kojemu je on materijalnopravni rok - pri čemu se posebno apostrofira okolnost da je njegovim odredbama, istina ne sasvim dosljedno imajući u vidu njegovo polje primjene ratione personae, izričajem propisano kako se propuštanjem tog roka „gube sva prava“ koja proizlaze iz navedenoga propisa. ${ }^{5}$ Ono proizlazi iz uobičajenog poimanja materijalnopravnog

2 V. Karlovčan - Đurović, Zakon o naknadi za imovinu oduzetu za vrijeme jugoslavenske komunističke vladavine - praksa Upravnog suda Republike Hrvatske, Zbornik Pravnog fakulteta Sveučilišta u Rijeci, vol. 29, 2008.; Gagro, Praksa Upravnog suda Republike Hrvatske i neke dvojbe u primjeni Zakona o naknadi za imovinu oduzetu za vrijeme jugoslavenske komunističke vladavine, Pravo u gospodarstvu, 2003., 6.; Crnić, J., O nekim spornim pitanjima iz zakona o naknadi za imovinu oduzetu za vrijeme jugoslavenske komunističke vladavine Informator, 1997., 4475.; Crnić, J., O nekim spornim pitanjima o povratu, odnosno naknadi za konfisciranu imovinu, Informator, 2002. i 2003., 5092. 5095, Golubić-Munjaković, Neke dvojbe u primjeni Zakona o naknadi za imovinu oduzetu za vrijeme jugoslavenske komunističke vladavine, Informator, 1998, 4650.; GolubićMunjaković, Pravni režim oduzetoga poljoprivrednog zemljišta u kontekstu Zakona o naknadi za imovinu oduzetu za vrijeme jugoslavenske komunističke vladavine, a vezano uz Zakon o poljoprivrednom zemljištu, Informator, 1997., 4542. itd.

3 V. Babić, Kunštek, Rok za pokretanje postupka - prijepor o njegovu računanju, Zbornik Pravnog fakulteta Sveučilišta u Rijeci, vol. 36., 2015.

4 Ugovor između Svete Stolice i Republike Hrvatske o gospodarskim pitanjima od 9. listopada 1998. V. Zakon o potvrđivanju Ugovora između Svete Stolice i Republike Hrvatske o gospodarskim pitanjima (Narodne novine - Međunarodni ugovori, 18/98.). Ugovor je stupio na snagu 14. prosinca iste godine. V. Objavu o stupanju na snagu Ugovora između Svete Stolice i Republike Hrvatske o gospodarskim pitanjima (Narodne novine - Međunarodni ugovori, 13/03.).

5 V. članke 65. ZON/96 i 7. ZON/02. Kad je u pitanju ZON/02 to ne bi bila točna tvrdnja, budući da on ne propisuje „gubitak svih prava“, već se ovaj zaključak u judikaturi izvodi iz okolnosti da bi domaći državljani i stranci trebali imati jednak položaj prema zakonu ,pa kad 
roka kao onoga o kojemu ovisi nastupanje učinaka propisanih materijalnopravnim propisima (nastanak, prestanak ili preinaka nekog prava).

Takvom stajalištu može se utemeljeno prigovoriti, s obzirom na to da rok za pokretanje bilo kojeg postupka, pa i postupka prema ZON-u, predstavlja rok unutar kojega se može poduzeti određena (procesna) radnja usmjerena na ostvarenje prava koje proizlazi iz materijalnopravnog propisa (prava na naknadu za oduzetu imovinu), a koje stranka u tom trenutku nema - budući da će ono kao subjektivno pravo (eventualno) nastati tek nakon donošenja odluke u tom postupku. Ovo osobito zbog toga jer postoji suglasnost u svezi s time da pravna narav roka ne ovisi o tome $\mathrm{u}$ kojem je propisu rok propisan (materijalnom ili procesnom), već o naravi prava s kojim je povezan. ${ }^{6}$

U tom smislu rok za pokretanje postupka može se smatrati procesnopravnim budući da je on povezan sa subjektivnim pravom poduzimanja određene postupovne radnje, a ne sa samim pravom koje bi u tom postupku stranka namjeravala ostvariti. ${ }^{7}$ U judikaturi se ovo stajalište sve više prihvaća. ${ }^{8}$

je tako propisano za domaće državljane, isto treba vrijediti i glede stranaca“.

V. presudu Visokog upravnog suda Republike Hrvatske Uss-6/2012-5 od 13. rujna 2012.:

„Pri tome Sud ne nalazi odlučnim što je u Zakonu o izmjenama i dopunama Zakona izostala odredba kojom se kao pravna posljedica podnošenja nepravodobnog zahtjeva po to zakonu, određuje gubitak prava. Taj je zakon, naime, donesen u izvršenju odluke Ustavnog suda Republike Hrvatske broj: U-I-673/1996 i dr. od 21. travnja 1999., kojom je ukinuta odredba članka 65. stavka 4. Zakona o naknadi o posljedicama propuštanja roka ukoliko se odnose na prijašnjeg vlasnika - stranu fizičku osobu. Međutim, uvažavajući okolnost da je gubitak prava kao posljedica nepravodobnog podnošenja zahtjeva, propisan za hrvatske državljane, Sud je cjelovitim tumačenjem odredbi Zakona o naknadi shvaćanja da ista posljedica mora nastupiti i u slučaju kad zahtjev nepravodobno podnesu kategorije građana određene člankom 7. stavkom 1. Zakona o izmjenama i dopunama Zakona. Drukčije tumačenje odredbe članka 7. Zakona o izmjenama i dopunama Zakona dovelo bi do neravnopravnosti hrvatskih državljana i stranih državljana i njihove nejednakosti pred zakonom, što je protivno odredbi članka 14. stavka 2. Ustava Republike Hrvatske (Narodne novine, broj 56/90., 8/98. - proč. tekst., 28/01., 41/01. - proč. tekst, 55/01.- ispr. i 85/10. - proč. tekst); kao i do diskriminacije hrvatskih državljana, što je protivno članku 14. Europske konvencije za zaštitu ljudskih prava i temeljnih sloboda (Narodne novine - Međunarodni ugovori, broj 18/97., 6/99., 8/99., 14/02., 9/05., 14/02., 13/03., 1/06 i 2/10.) u svezi sa zaštitom vlasništva zajamčene člankom 1. Protokola 1 uz tu Konvenciju."

6 V. Dika, Parnične radnje, Zagreb, 2008., str. 54.

7 V. o tome više u Babić, Kunštek, op. cit., 425. et seq.

8 Ibid., str. 429. i 431. V. odluku Ustavnog suda Republike Hrvatske (dalje: Ustavni sud) U-III-675/2009 od 8. veljače 2012:

„Zadnji dan roka za podnošenje predmetne tužbe podnositeljici je isticao 21. svibnja 2006. Uvidom u kalendar za 2006. godinu (mjesece travanj i svibanj) Ustavni sud je utvrdio kako je 21. svibanj 2006. bila nedjelja. Zadnji dan roka trebao se stoga (u smislu članka 112. stavka 4. ZPP-a) računati prvi sljedeći radni dan, dakle 22. svibnja 2006....“

V. i odluku U-III-4117/2003 od 20. svibnja 2004.:

„Na temelju navedenih činjenica, ovaj Sud utvrđuje da je u konkretnom slučaju zadnji dan roka za podnošenje tužbe podnositeljice padao u neradni dan Upravnog suda Republike Hrvatske pa se taj rok, sukladno mjerodavnim odredbama Zakona o parničnom postupku, morao produžiti na prvi sljedeći radni dan, a to je bio ponedjeljak 18. studenoga 2002. godine......" 
Inače, razlikovanje procesnopravnih i materijalnih rokova, vezano uz pravila o njihovu održanju ako zadnji dan roka pada u neradni dan, nema praktičnog značenja budući da za i jedne i druge vrijede ista pravila - istina sadržana u različitim propisima. ${ }^{9}$ Ova napomena vrijedi i za računanje rokova u pravu Europske unije - ako u obzir dolazi primjena njenog posebnog propisa koji se odnosi na ovu problematiku. ${ }^{10}$

Zbog navedenoga, posebno interesantnom ukazuje se recentna odluka Ustavnog suda Republike Hrvatske koji se izričajem opredijelio za stajalište prema kojemu je rok za pokretanje postupka prema ZON-u procesnopravni rok. ${ }^{11}$ Time je, barem u judikaturi, navedena dvojba riješena. U njoj se posebno ističe:

Ustavni sud utvrđuje sljedeća načelna pravna stajališta:

- i u članku 65. ZoNak-a/96 i u članku 7. ZID-a ZoNak-a/02 riječ je o tipičnom i uobičajenom procesnopravnom roku u upravnom pravu prekluzivnog karaktera, koji dovodi do prestanka procesnog ovlaštenja za pokretanje upravnog postupka zbog propuštanja roka za podnošenje zahtjeva za priznavanje prava na naknadu za oduzetu imovinu;

- na računanje isteka roka za podnošenje zahtjeva za priznavanje prava na naknadu za oduzetu imovinu u smislu članka 65. ZoNak-a/96 i članka 7. ZID-a ZoNak-a/02 primjenjuje se članak 101. stavak 2. ZUP-a/91 (članak 81. stavak 2. ZUP-a/09). ${ }^{12}$

Iz navedenoga proizlazi da je Ustavni sud promijenio svoje ranije stajalište, odnosno kako smatra da je neprihvatljivo da se navedeni rok smatra rokom materijalnopravne naravi, što se u spomenutoj odluci posebno i navodi. ${ }^{13} \mathrm{U}$ njoj se ističe

Tako i Vrhovni sud Republike Hrvatske (Rev - 930/11-2 od 11. prosinca 2013.):

„Prema shvaćanju revizijskog suda rok za podnošenje tužbe zbog smetanja posjeda (subjektivni od 30 dana od saznanja za čin smetanja i počinitelja i objektivni od godine dana od počinjenog smetanja) je procesne naravi, budući je posljedica da tužba nije podnesena u roku odbačaj tužbe, a ne odbijanje tužbenog zahtjeva. Istina je da su navedeni rokovi smješteni u materijalni propis čl. 21. st. 3. ZV, no time rok za podnošenje tužbe, odnosno za traženje sudske zaštite nije postao materijalnopravni rok....."

9 Ibid., str. 430.

10 V. Regulation (EEC, Euratom) No 1182/71 of the Council of 3 June 1971 determining the rules applicable to periods, dates and time limits [Uredba Vijeća (EEZ, Euroatom) br. 1182/71 od 3. lipnja 1971. o utvrđivanju pravila koja se primjenjuju na razdoblja, datume i rokove], članak 2. stavak 4.:

Where the last day of a period expressed otherwise than in hours is a public holiday, Sunday or Saturday, the period shall end with the expiry of the last hour of the following working day (Kada je posljednji dan razdoblja koje se izražava na drugi način osim u satima blagdan, subota ili nedjelja, razdoblje završava istekom posljednjeg sata sljedećeg radnog dana).

11 U-III -5694/13 od 1. ožujka 2016.

12 Točka 46.

13 V. točku 36: “....u nastavku se obrazlažu razlozi zbog kojih je Ustavni sud, vodeći se razlozima pravne sigurnosti, ocijenio nužnim promijeniti svoj ocjenu da je ustavnopravno prihvatljivo pravno shvaćanje VUSRH-a prema kojem je rok za podnošenje zahtjeva za priznavanje prava na naknadu za oduzetu imovinu materijalnopravne prirode..." 
da narav roka iz članka 65. ZON/96 ne determinira to što se u njemu predviđa „gubitak svih prava“ iz tog propisa u slučaju njegova propuštanja. Možemo ovome dodati i kako članak 7. ZON/02 čak i ne predviđa takvu posljedicu, što se teško može smatrati redakcijskom pogreškom. ${ }^{14}$

...dio odredbe o "gubitku svih prava" podnositelja zahtjeva uslijed propuštanja tog roka mora se tumačiti smisleno, u skladu s načelom pravne konzistentnosti i služeći se argumentom zdravog razuma.

Protumači li se na taj način, onda dio odredbe o "gubitku svih prava" iz Zakona o naknadi nikako ne može dovesti do prekvalifikacije klasičnog procesnopravnog roka za podnošenje zahtjeva u materijalnopravni jer prava o kojima je riječ još nisu ni stečena pa se ne mogu ni “izgubiti“. Štoviše, ta se prava ne stječu ni samim činom podnošenja zahtjeva u propisanom roku. Ona se mogu steći samo upravnim aktom koji se donosi u upravnom postupku u kojem se apstraktna pravna norma konkretizira na pojedinačni slučaj. ${ }^{15}$

U odluci se dodatno navodi:

Proizlazi da je jedini relevantni dio članka 65. stavka 4. ZoNak-a/96 onaj o odbacivanju zahtjeva uslijed propuštanja roka za njegovo podnošenje. S obzirom da podnositelj zahtjeva još nema nikakva prava iz Zakona o naknadi, dijelu odredbe koji govori da će se zahtjev odbaciti "pa podnositelj gubi sva prava iz ovoga Zakona" ne može se davati pravno značenje koje on nema.

Pri tumačenju tog dijela odredbe mora se poći od uobičajenih pravnih posljedica koje propuštanje procesnopravnog roka ima za podnositelja: on gubi sva procesna ovlaštenja za pokretanje upravnog postupka. Taj gubitak onda praktički dovodi do nemogućnosti ostvarenja subjektivnog prava koje bi stranka ostvarila u upravnom postupku da je zahtjev podnijela u roku (pod uvjetom da ispunjava zakonske uvjete za priznavanje materijalnog prava)........ Nitko od prijašnjih vlasnika još nije stekao pravo na povrat ili naknadu po odredbama tog zakona. Člankom 7. stavkom 1. ZID-a ZoNak-a/02 tek im je otvorena pravna mogućnost da u (procesnopravnom) roku podnesu zahtjev za priznavanje prava. ${ }^{16}$

U svezi s ovime, a imajući u vidu da je zbog ovakvog stajališta odbačen veći broj zahtjeva za naknadu koji su podneseni 7. siječnja 2003. Ustavni sud je u točki IV. odlučio:

Na temelju članka 31. stavaka 4. i 5. Ustavnog zakona o Ustavnom sudu Republike Hrvatske ("Narodne novine" broj 99/99., 29/02., 49/02.) Ustavni sud povjerava provedbu ove odluke nadležnim upravnim tijelima i upravnim sudovima te određuje:

14 V. bilješku supra 5.

15 Točka 38.

16 Točka 39. 
svi zahtjevi za priznavanje prava na naknadu za oduzetu imovinu podneseni nadležnom upravnom tijelu 7. siječnja 2003. na temelju članka 7. stavka 1. Zakona o izmjenama i dopunama Zakona o naknadi za imovinu oduzetu za vrijeme jugoslavenske komunističke vladavine ("Narodne novine" broj 80/02., 81/02. - ispravak) bili su pravodobni, pa adresati koji su ih podnijeli 7. siječnja 2003., ali su im zahtjevi odbačeni zbog nepravodobnosti, mogu ponovo podnijeti isti zahtjev u roku od šest mjeseci računajući od prvog sljedećeg dana nakon objave ove odluke u "Narodnim novinama".

\section{II.}

Kad je u pitanju Ugovor o gospodarskim pitanjima, izvjesno je kako on sadrži odredbe koje bi trebale utjecati na apsolutnu (ne)nadležnost tijela koja prema ZON-u inače donose odluke u predmetima naknade za imovinu oduzetu za vrijeme jugoslavenske komunističke vladavine. ${ }^{17}$

Naime, taj međunarodni ugovor predviđa posebno tijelo/tijela koja bi bila nadležna za donošenje odluka u ovim predmetima - kad su u pitanju pravne osobe Katoličke Crkve. Međutim, čini se kako se iz postupanja upravnih tijela Republike Hrvatske, ali i pravnih osoba Katoličke Crkve može zaključiti da one ove odredbe ne uzimaju u obzir. Stoga će se u nastavku analizirati moguće posljedice takve prakse.

Iz odredbe članka 10. stavka 1 . ZON-a moglo bi se zaključiti kako se on ratione personae ne primjenjuje na one osobe čije je pravo na naknadu za oduzetu imovinu uređeno međunarodnim ugovorom koji obvezuje Republiku Hrvatsku. ${ }^{18}$ Njegova bi primjena u odnosu na ove osobe bila moguća samo ako to izričito propisuje međunarodni ugovor. ${ }^{19}$

Opći režim naknade za oduzetu imovinu, dakle onaj koji uređuje ZON, glede nadležnosti za postupanje u tim stvarima predviđa „,nadležnu službu“ onog ureda državne uprave u županiji na čijem se području nalazi imovina koja je predmet naknade.$^{20}$ Navedeno tijelo postupa po pravilima koja predviđa ZON, te podredno prema pravilima "starog” Zakona o općem upravnom postupku (dalje: „stari“

17 V. Staničić, Pitanje povrata imovine oduzete Katoličkoj Crkvi i problema tumačenja Ugovora o pravnim pitanjima između Republike Hrvatske i Svete Stolice, Informator, 6362 od 20. travnja 2015.

18 „Prijašnji vlasnik nema pravo na naknadu za oduzetu imovinu u slučaju kada je pitanje naknade riješeno međudržavnim sporazumima.“

19 V. odredbu članka 10. stavka 2.: „Iznimno od odredbe stavka 1. ovoga članka, prava propisana ovim Zakonom mogu steći i strane fizičke i pravne osobe ako se to utvrdi međudržavnim sporazumima."

20 Članak 64. stavak 2:

„Zahtjev se podnosi nadležnoj službi ureda državne uprave prema mjestu gdje se nalazi imovina koja je predmet naknade.“ 
ZUP). ${ }^{21}$ Ovo zbog toga što su svi postupci prema ZON-u pokrenuti u vrijeme važenja toga Zakona te s obzirom na prijelazne odredbe "novoga" Zakona o općem upravnom postupku. ${ }^{22}$

S druge, strane, Ugovor o gospodarskim pitanjima sadrži odredbe iz kojih bi se trebalo zaključiti da bi za donošenje odluka o naknadi za imovinu oduzetu za vrijeme jugoslavenske komunističke vladavine, ovisno o tome u kakvom se obliku daje naknada, bila nadležna neka druga tijela. U tom smislu relevantne su njegove sljedeće odredbe:

\section{Članak 3.}

Republika Hrvatska se obvezuje da će Katoličkoj Crkvi, u razumnom roku, vratiti u naravi imovinu koju je moguće vratiti prema zakonskim odredbama.

U roku od šest mjeseci po stupanju na snagu ovoga Ugovora, mješovito povjerenstvo - sastavljeno od jednakog broja predstavnika Vlade Republike Hrvatske i Hrvatske biskupske konferencije - priredit će popis imovine koja će biti vraćena, s naznakom roka povratka.

\section{Članak 4.}

Republika Hrvatska, u dogovoru s mjerodavnim vlastima Katoličke Crkve i u skladu sa zakonskim odredbama, izvršit će prikladnu zamjenu za dio dobara koji nije u stanju vratiti Katoličkoj Crkvi. Zamjenu dobara i rokove također će utvrditi mješovito povjerenstvo u roku od godine dana od stupanja na snagu ovoga Ugovora.

\section{Članak 5.}

Republika Hrvatska će pravnim osobama Katoličke Crkve od godine 2000., kao naknadu za oduzeta dobra koja nije moguće vratiti, isplaćivati primjerenu novčanu naknadu u četiri godišnja obroka.

Ukupan iznos naknade za oduzetu imovinu, koja će se isplaćivati u novcu, utvrdit će crkveno-državno povjerenstvo stručnjaka na temelju procjene vrijednosti tih dobara, a u skladu sa zakonskim odredbama, najkasnije u roku od jedne godine od stupanja na snagu ovoga Ugovora.

Mjerodavno tijelo Republike Hrvatske isplaćivat će Katoličkoj Crkvi novčani iznos svaka tri mjeseca na račun Središnjega fonda Hrvatske biskupske konferencije za crkvene ustanove. Središnji fond će dospjeli iznos dostavljati (nad) biskupijama te ustanovama posvećenog života i družbama apostolskog života, na temelju vrijednosti oduzete imovine.

Očigledno je kako prethodno navedene odredbe nisu dostatno jasne. Tako se, primjerice postavlja pitanje je li, unatoč njihovu postojanju, moguća primjena ZON-a općenito, pa i glede nadležnosti tijela za vođenje postupka i donošenje odluka? Dodatno, budući da iz Ugovora o gospodarskim pitanjima proizlazi

21 V. članak 68.:

„Postupak naknade za oduzetu imovinu provodi se po odredbama Zakona o općem upravnom postupku ("Narodne novine”, br. 53/91.), ako ovim Zakonom nije drukčije propisano.“

22 Narodne novine, 47/09. V. članak 168.:

„Postupci započeti do stupanja na snagu ovoga Zakona nastavit će se i dovršiti prema odredbama Zakona o općem upravnom postupku (»Narodne novine«, br. 53/91. i 103/96.).“ 
kako su njegovi izvornici oba teksta, onaj na hrvatskom i onaj talijanskom jeziku - moguće su i jezične dvojbe. ${ }^{23}$ Također, notorno je kako ugovorne strane nisu postupile sukladno članku 3. unutar roka koji je u njemu određen. Znači li to, da nakon njegova proteka roka ne postoji nadležnost mješovitog povjerenstva da "priredi" popis imovine glede koje će se primjenjivati temeljno pravilo o naturalnoj restituciji? Valja zapaziti i kako iz članka 4. prima faciae ne proizlazi postojanje nadležnosti "mješovitog povjerenstva", već potreba postizanja dodatnog sporazuma između u njemu navedenih (odredivih) tijela glede oduzete imovine za koju nije moguće primijeniti pravilo o naturalnoj restituciji - u slučajevima kad bi se naknada davala prijenosom u vlasništvo neke druge imovine (,prikladna zamjena“). Međutim, iz druge rečenice te odredbe trebalo bi zaključiti kako bi ono, u slučaju odsutnosti dogovora, ipak moglo biti nadležno. Dakako, moglo bi se postaviti pitanje postoji li njegova nadležnost nakon proteka roka koji je naveden u toj odredbi. Kad je u pitanju imovina za koju nije moguća niti naturalna restitucija, ni naknada u „zamjenskim dobrima“, predviđeno je kako će se dati naknada u novcu - koja bi trebala biti "primjerena", o čemu bi odluku trebalo donijeti mješovito crkveno-državno povjerenstvo. Pri tome treba imati u vidu da je ono nadležno samo za određivanje ukupnog iznosa novčane naknade, ali ne i za donošenje odluke o tome je li moguć koji od druga dva oblika naknade - za to izričajem nije određeno niti jedno tijelo. Stoga se, primjerice može pretpostaviti da bi se odluka o naknadi u novcu mogla donijeti uvijek kada ne postoji odluka o kakvom drugom obliku naknade. Dakako, može se smatrati i nešto drugo, napose da je postojanje odluke o nemogućnosti drugih oblika naknade pretpostavka za donošenje odluke o naknadi u novcu. Ovome treba dodati da iz ove odredbe proizlazi kako bi postupanje crkvenodržavnog povjerenstva trebalo biti sukladno "zakonskim odredbama", ali je nejasno odnosi li se taj dio rečenice na "ukupan iznos naknade" ili na "procjenu vrijednosti" oduzete imovine. Dodatno je (donekle) nejasno predstavlja li „crkveno-državno povjerenstvo" tijelo koje bi bilo različito od „mješovitog povjerenstva“". Trebalo bi kazati i kako izrazi „prikladna zamjena“ (appropriata sustituzione) i „primjerena naknada“" (equo compenso) koji se koriste u Ugovoru o gospodarskim pitanjima nemaju dostatno jasna značenja - pa su moguća različita tumačenja njihova sadržaja.

U svrhu detaljnije analize ove problematike treba imati u vidu da postoji niz odluka upravnih tijela Republike Hrvatske (rješenja) kojima se, primjerice: a) utvrđuje pravo određene pravne osobe Katoličke Crkve na naknadu za oduzetu imovinu, ${ }^{24}$ b) da se oduzeta imovina ne može vratiti u posjed ovlašteniku naknade, ${ }^{25}$

23 V. napomenu na kraju tekstu Ugovora o gospodarskim pitanjima:

„Potpisano u Zagrebu, 9. listopada 1998., u dva izvorna i podjednako vjerodostojna primjerka na hrvatskom i na talijanskom jeziku.“

$24 \mathrm{Na}$ temelju članka 12. stavka 1. ZON-a:

„Pravne osobe, odnosno njihovi pravni sljednici kojima je imovina oduzeta na temelju propisa iz članka 2. te akata i načina propisanih člankom 3. ovoga Zakona imaju pravo na naknadu za oduzetu imovinu samo ako su do donošenja ovoga Zakona na teritoriju Republike Hrvatske održale neprekinuto pravno sljedništvo, obavljale djelatnost i imale sjedište.“

25 Primjerice imajući u vidu odredbe članka 17. stavaka 1. i 5. ZON-a: 
c) da će se za oduzetu nekretninu odrediti naknada na temelju Ugovora između Svete Stolice i Republike Hrvatske o gospodarskim pitanjima te d) kako je obveznik naknade Republika Hrvatska. ${ }^{26}$ Nadležna upravna tijela (uglavnom) primjenjuju hrvatske nacionalne propise, ${ }^{27}$ pri čemu ipak (nedostatno) imaju u vidu i odredbe međunarodnog ugovora (Ugovora o gospodarskim pitanjima) koji je po pravnom značenju iznad hrvatskih zakona. ${ }^{28}$ Primjenom nacionalnih (hrvatskih) propisa određuju svoju nadležnost ${ }^{29}$ - što se ne može smatrati pravilnim postupanjem, ako se uzmu u obzir odredbe međunarodnog ugovora, ali i odredbe Zakona o općem upravnom postupku o nadležnosti. ${ }^{30}$ Nadležna upravna tijela u izreci katkad

"Neizgrađeno građevinsko zemljište koje je u društveno vlasništvo preneseno na temelju propisa iz članka 2. te akata i načina propisanih člankom 3. ovoga Zakona i koje je na temelju pravomoćne odluke nadležnoga tijela oduzeto iz posjeda prijašnjih vlasnika ili osobe na koju je pravo prenio prijašnji vlasnik, a kojim općina, odnosno grad do stupanja na snagu ovoga Zakona nije dalje raspolagala ili koje do donošenja ovoga Zakona nije privedeno namjeni, dati će se u vlasništvo prijašnjem vlasniku na njegov zahtjev.

Pod zemljištem privedenim namjeni smatra se ono zemljište na kojem je izgrađen objekt ili su izvedeni znatniji radovi na objektu kao i ono zemljište na kojem je općina, odnosno grad izvršila pripremu za izgradnju.“"

$26 \mathrm{Na}$ temelju prethodno navedenog članka 4. Ugovora o gospodarskim pitanjima. Usp. s člankom 13. ZON-a:

"Obveznik naknade u naravi je fizička ili pravna osoba u čijoj imovini se nalazi imovina koja se na temelju ovoga Zakona daje prijašnjem vlasniku, ako ovim Zakonom za određenu imovinu nije drukčije propisano.

Obveznik naknade u dionicama, odnosno udjelima je Hrvatski fond za privatizaciju, glede naknade za oduzeta poduzeća, te u slučajevima iz članka 44. stavka 3. i članka 53. ovoga Zakona.

Obveznik naknade u novcu i obveznicama Republike Hrvatske je Fond za naknadu oduzete imovine (u daljnjem tekstu: Fond), glede ostale oduzete imovine."

27 U konkretnom slučaju - ZON i Zakon o općem upravnom postupku (Narodne novine, 53/1991. i 103/1996.).

28 V. Ustav Republike Hrvatske (Narodne novine, 56/90., 135/97., 113/00., 28/01., 76/10., 85/10. - pročišćeni tekst, 5/14), članak 141.:

„Međunarodni ugovori koji su sklopljeni i potvrđeni u skladu s Ustavom i objavljeni, a koji su na snazi, čine dio unutarnjega pravnog poretka Republike Hrvatske, a po pravnoj su snazi iznad zakona. Njihove se odredbe mogu mijenjati ili ukidati samo uz uvjete i na način koji su u njima utvrđeni, ili suglasno općim pravilima međunarodnog prava."

$29 \mathrm{Na}$ temelju odredbe članka 69. stavka 1 . ZON-a.

Dakako, treba upozoriti i na odredbu članka 24. „staroga“ ZUP-a koja glasi:

„Organ koji je pokrenuo postupak kao mjesno nadležan zadržava nadležnost i kad u toku postupka nastupe okolnosti prema kojima bi bio mjesno nadležan drugi organ. Organ koji je pokrenuo postupak može ustupiti predmet organu koji je prema novim okolnostima postao mjesno nadležan, ako se time znatno olakšava postupak, osobito za stranku.“

30 „Stari“ ZUP u svezi s pitanjima nadležnosti sadrži sljedeće odredbe:

Članak 25.

(1) Svaki organ pazi po službenoj dužnosti u toku cijelog postupka na svoju stvarnu i mjesnu nadležnost.

(2) Ako organ nade da nije nadležan za rad u određenoj upravnoj stvari, postupit će na način propisan u članku 66. st. (3) i (4) ovog zakona.

(3) Ako je nenadležni organ izvršio koju radnju postupka, nadležni organ kojem je stvar ustupljena cijenit će da li će koju od tih radnji ponoviti. 
posebno navode kako će se naknada za oduzetu imovinu „odrediti na temelju Ugovora između Svete Stolice i Republike Hrvatske o gospodarskim pitanjima.“ Pri tome posebno ističu kako ne postoji obveza tijela koje je donijelo rješenje „naći zamjensko zemljište, jer zamjenska dobra određuje mješovito povjerenstvo u skladu sa člankom 4. Ugovora između Svete Stolice i Republike Hrvatske, kojim nije propisana obveza prvostupanjskog tijela da pronalazi ta dobra" te da će se za imovinu koja se ne može naturalno vratiti naći odgovarajuća zamjena, dok će se za ostalu imovinu isplatiti primjerena naknada (članak 5. stavak 1. Ugovora). Dodatno se apostrofira i kako ne postoji nadležnost upravnog tijela koje je donijelo odluku utvrditi visinu novčane naknade budući da je za to nadležno prethodno spomenuto crkveno-državno povjerenstvo stručnjaka. ${ }^{31}$ Iz takve odluke, ali i iz samoga Ugovora o gospodarskim pitanjima, ne može se sa sigurnošću zaključiti treba li se za oduzetu imovinu, ako naturalna restitucija ne dolazi u obzir, prvenstveno naći odgovarajuća zamjena, a tek ako ni to nije moguće, isplatiti novčana naknada, ili bi povjerenstvo (i koje) ${ }^{32}$ slobodno moglo birati između ove dvije mogućnosti. Drugim riječima, je li obveza Republike Hrvatske alternativna ili bi se o drugoj alternativi trebalo odlučivati tek ako zamjena nije moguća (dakle, o novčanoj naknadi bi se odlučivalo tek ako se ispuni suspenzivni uvjet - da mješovito povjerenstvo utvrdi kako nije moguće naći odgovarajuću zamjenu). Kad bi relevantni dio odrebe članka 5. tog ugovora glasio „Republika Hrvatska će pravnim osobama Katoličke Crkve od godine 2000., kao naknadu za oduzeta dobra koja nije moguće vratiti ili za koja nije moguće naći odgovarajuću zamjenu, isplaćivati primjerenu novčanu naknadu....." - situacija bi, glede nastanka obveze isplate novčane naknade, bila daleko jasnija. Ovako proizlazi da su moguće obje inačice - ovisno o tomu što ugovorne strane naknadno dogovore. U odsutnosti takva dogovora, jedna od njih bi mogla smatrati kako obveza na naknadu u novcu nastaje nakon ispunjenja suspenzivnog uvjeta (nakon što mješovito povjerenstvo utvrdi kako odgovarajuću zamjenu u dobrima

\section{Članak 66.}

(3) Ako organ nije nadležan za primitak pismenog podneska odnosno priopćenja na zapisnik, službena osoba tog organa upozorit će na to podnosioca i uputiti ga organu nadležnome za primitak. Ako podnosilac i pored toga zahtijeva da se njegov podnesak primi, službena osoba dužna je primiti takav podnesak odnosno usmeno priopćenje. Ako organ nađe da nije nadležan za rad o takvu podnesku, donijet će zaključak kojim će odbaciti podnesak zbog nenadležnosti.

(4) Kad organ dobije poštom podnesak za čiji primitak nije nadležan, a nesumnjivo je koji je organ nadležan za primitak, poslat će podnesak bez odgode nadležnom organu odnosno sudu i o tome obavijestiti stranku. Ako organ koji je dobio podnesak ne može utvrditi koji je organ nadležan za rad o podnesku, donijet će bez odgode zaključak kojim će odbaciti podnesak zbog nenadležnosti i zaključak odmah dostaviti stranci.........

31 V. primjerice Rješenje Gradskog ureda za imovinsko-pravne poslove Grada Zagreba, Odjela za upravno-pravne poslove, Središnji odsjek, Zagreb, klasa: UP/I-942-0103-01/145; ur. broj: 251-14-02/103-07-13 od 6. studenog 2007.

32 Naime, postoje dva povjerenstva: a) mješovito iz članka 3. stavka 2. i b) crkveno-državno povjerenstvo iz članka 5. stavka 2. 
nije moguće dati, dakle radilo bi se o nekoj vrsti ,eventualne“ obveze - pod suspenzivnim uvjetom), ${ }^{33}$ dok bi druga mogla smatrati kako se radi o alternativnoj obvezi, odnosno da će se pristupiti naknadi u novcu i kad je načelno moguće dati prikladnu zamjenu u dobrima, ali je izostala odluka mješovitog povjerenstva u tom pravcu.

Stoga se ukazuje uputnim i potrebnim da mješovito povjerenstvo o tomu prethodno zauzme stajalište. ${ }^{34}$ Dakako, ako se pokaže kako ni to nije moguće, tumačenje navedene odredbe mogu dati i ugovorne strane. ${ }^{35}$ Radilo bi se o autentičnom tumačenju. ${ }^{36}$

Problemska pitanja načelno se mogu postaviti kako slijedi: a) kako postupiti ako ne postoji suglasnost glede načina na koji će se nekoj pravnoj osobi Katoličke Crkve dati naknada za oduzetu imovinu te b) ako postoji takva suglasnost - koji je opseg naknade (prikladne zamjene ili primjerene novčane nadoknade)?

Dakako, primarni problem svodi se na to postoji li uopće nadležnost upravnog tijela Republike Hrvatske donositi odluke u ovim stvarima. Drugim riječima, može li se odluka o tome koja će se imovina vratiti, odnosno glede koje postoji takvo pravo pravnih osoba Katoličke Crkve, donositi u upravnom postupku koji, koristeći se svojim javnopravnim ovlastima (iure imperii), vodi jedna od ugovornih strana iz međunarodnog ugovora - ili bi za to postojala nadležnost povjerenstva iz članka 3. stavka 2. Ugovora o gospodarskim pitanjima? Doslovnim (bukvalnim) tumačenjem te odredbe može se zaključiti da će popis imovine na koju se odnosi pravo na povrat „prirediti“ mješovito povjerenstvo. Dakako, potpuno je jasno da ono tu radnju (,„priređivanje“" popisa) ne može obaviti ako prethodno ne donese

33 Pri čemu bi mogao nastati dodatni spor u svezi s time kad će se smatrati da nije moguće dati „odgovarajuću zamjenu“ u dobrima.

34 V. članak 13. stavak 2. Ugovora o gospodarskim pitanjima: „Mješovito povjerenstvo će dogovoriti pojedinosti u svezi s primjenom navedenih načela.“

35 V. članak 14.

„Sveta Stolica i Republika Hrvatska zajedničkim će dogovorom rješavati moguće dvojbe ili poteškoće koje bi mogle nastati u svezi s tumačenjem ili provođenjem bilo koje točke ovoga Ugovora."

36 V. Degan, Međunarodno pravo, Zagreb, 2011., str. 139: „Najveću slobodu u tumačenju uživaju same stranke, kada zajednički tumače njihov vlastiti ugovor. One obavljaju tzv. autentično tumačenje, koje obvezuje sva druga tijela. Ne samo da one mogu pribjeći bilo kojoj metodi tumačenja, uključujući i funkcionalnu, nego, ako žele, mogu zajedničkim sporazumom izvršiti izmjenu ugovora ili ga dokinuti neovisno o odredbama u njemu o njegovu prestanku. No uvjet za autentično tumačenje ugovora jest jednoglasnost svih njegovih stranaka. Savjetodavno mišljenje Stalnoga suda međunarodne pravde iz 1923. o pitanju Jaworzine pozvalo se na „tradicionalno načelo": ejus est interpretare legem cujus condere, objasnivši ga na sljedeći način: „,... utemeljeno je načelo da pravo autentičnoga tumačenja nekoga pravnog pravila pripada jedino osobi ili tijelu koje ima moć da ga izmijeni ili dokine" (Series B, No. 8, p. 37).

Iz gornjega proizlazi suprotno načelo, da jednostrano tumačenje nekoga ugovora, ili ono na koje nisu pristale sve njegove stranke, pravno ne obvezuje stranke koje na njega nisu dale svoj pristanak." 
odluku o tomu postoji li uopće pravo na povrat u odnosu na određenu imovinu. ${ }^{37}$ Slijedom navedenoga, u najmanju je ruku dvojbeno bi li odluku o tomu trebalo donijeti mješovito povjerenstvo ili neko upravno tijelo Republike Hrvatske. Ako se uzme da je to ipak upravno tijelo Republike Hrvatske, onda bi odredba članka 3. stavka 2. Ugovora zapravo bila nepotrebna, jer bi mješovito povjerenstvo obavljalo samo tehničku radnju - prepisivanje nekretnina iz rješenja nadležnih upravnih tijela Republike Hrvatske u popis nekretnina koje će se (naturalno) vratiti, slijedom čega jedna od ugovornih strana zapravo ne bi bila ravnopravna. Naime, ona uopće ne bi sudjelovala u postupku donošenja odluke, odnosno mogla bi jedino odbiti sudjelovati u ,priređivanju popisa“, što joj očigledno nije u interesu. Druga preostala mogućnost bila bi prihvatiti (jednostranu) odluku druge ugovorne strane, što je protivno općim načelima Povelje Ujedinjenih naroda ${ }^{38}$ i Bečke konvencije o pravu međunarodnih ugovora (suverena jednakost). ${ }^{39}$ Inače, i odredbe ovoga

37 O tumačenju ugovora, v. Degan, op. cit., str. 138.: „(a ) Najstarija je subjektivna metoda, koja polazi od prvobitne namjere država pregovarateljica. Ta se metoda s nepovjerenjem odnosi prema tekstu ugovora, jer polazi od toga da riječi nemaju značenje, osim ako ne izražavaju namjeru stranaka kao najbitniji element ugovora.52 Većina odredaba o tumačenju privatnopravnih pogodbi $\mathrm{u}$ građanskim zakonicima država polazi od subjektivne metode njihova tumačenja.

(b) Tekstualna metoda, naprotiv, uzima sam tekst ugovora kao najpouzdaniji dokaz prvobitne namjere ugovornica, koji pri tumačenju treba iskoristiti koliko je to moguće. Prema tom pristupu, tek ako je tekst ugovora dvosmislen ili nejasan, ili dovodi do besmislenog ili nerazumnog ishoda, dopušteno je istraživati namjeru stranaka na temelju drugih dokaza.

(c) I napokon, modernija funkcionalna (ili teleološka) metoda tumačenja ne osvrće se ni na prvobitnu namjeru, pa kadšto ni na tekst ugovora. Primjenom te metode ugovor se tumači s obzirom na njegov predmet i svrhu u vremenu kad se obavlja tumačenje. Predmet i svrha mnogih mnogostranih ugovora mogu se protekom vremena izmijeniti.“

38 Narodne novine - Međunarodni ugovori - 15/94. V. preambulu te članke 1. i 55.

V. Degan, op. cit., str. 237.: „To načelo u Povelji UN-a nije najsretnije formulirano, jer je, zapravo, riječ o dvama pravnim načelima: onome o suverenosti koje smo usput opisali (supra, §30, pod 2 (iii)), i onome o (pravnoj) jednakosti svih suverenih država. No, s obzirom na to da je nakon Povelje UN-a izraz „suverena jednakost” ovladao u svim međunarodnim instrumentima, uključujući i Deklaraciju iz 1970, nije ga više moguće zanemariti. Razlike između država očite su i ta se značajka međunarodne zajednice nikada neće moći prevladati. Države se međusobno veoma mnogo razlikuju u broju stanovnika, po veličini državnoga područja, u prirodnim izvorima, gospodarskom potencijalu, vojnoj moći, dohotku po stanovniku i dr. No, unatoč tim razlikama, sve su suverene države pravno jednake, kao što su i pojedinci jednaki u pravima u svakome unutarnjem pravnom poretku dostojnom toga imena. Pravna jednakost država proizlazi dakle iz svojstva države da je suverena i da je subjekt međunarodnoga prava. Posljedica načela pravne jednakosti svih država jest da, kada se god neko pitanje ima urediti sporazumno, svaka država ima pravo na glas. A ako nema drukčijega sporazuma, svaka država ima jedan glas. Na diplomatskim konferencijama, u međunarodnim organima, te u tekstovima međunarodnih ugovora, države se obično svrstavaju po abecednom redoslijedu njihovih imena (nekoć na francuskom, a danas pretežito na engleskom jeziku). Redoslijed njihova glasanja također se obavlja po abecednom redu. Često se uvodi tzv. roll call glasanje. Kockom se izvuče ime države koja prva glasa, a potom glasaju sve države po abecednom redu do kraja, te potom od početka takvoga popisa."

39 Narodne novine - Međunarodni ugovori - 16/93. V. preambulu: „Države stranke ove Konvencije..... svjesne načela međunarodnog prava utjelovljenih u Povelji Ujedinjenih naroda, 
međunarodnog ugovora mogle bi se tumačiti prema toj Konvenciji neovisno o tome što ga Država Vatikanskog Grada nije ni potpisala ni ratificirala, jer je općeprihvaćeno da ona predstavlja dio običajnog međunarodnog prava. ${ }^{40}$

Potrebno je istaknuti kako prema članku 10. spomenutoga Zakona o naknadi, nakon njegove novele iz 2002., proizlazi da prijašnji vlasnik nema pravo na

kao što su načela ravnopravnosti i samoodređenja naroda, suverene jednakosti i nezavisnosti svih država....".

40 Primjerice, tako smatraju i Sjedinjene Države. V. objavu na internet stranici US Departmet of State (stranica posjećena 3. ožujka 2016.):

„The United States signed the treaty on April 24, 1970. The U.S. Senate has not given its advice and consent to the treaty. The United States considers many of the provisions of the Vienna Convention on the Law of Treaties to constitute customary international law on the law of treaties".

V. članak 31. Konvencije:

Opće pravilo o tumačenju

1. Ugovor se mora tumačiti u dobroj vjeri, prema uobičajenom smislu izraza iz ugovora u njihovu kontekstu i u svjetlu predmeta i svrhe ugovora.

2. U svrhu tumačenja ugovora, osim teksta, uključujući preambulu i priloge, kontekst obuhvaća:

(a) svaki sporazum koji se odnosi na ugovor, a kojeg su sve stranke sklopile u svezi s ugovorom;

(b) svaku ispravu koju jedna ili više stranaka sastave u svezi s ugovorom, a koju ostale stranke prihvate kao ispravu koja se odnosi na ugovor.

3. Zajedno s kontekstom, vodit će se računa:

(a) o svakom naknadnom sporazumu između stranaka o tumačenju ugovora ili o primjeni njegovih odredba;

(b) o svakoj naknadnoj praksi u primjeni ugovora kojom se ustanovljuje sporazum između stranaka o tumačenju ugovora;

(c) o svakom mjerodavnom pravilu međunarodnog prava primjenjivom na odnose između stranaka.

4. Poseban smisao pridaje se nekom izrazu ako je ustanovljeno da je to bila namjera stranaka.

Članak 32.

Dopunska sredstva tumačenja

Na dopunska sredstva tumačenja, uključujući pripremne radove i okolnosti pod kojima je ugovor sklopljen, može se pozivati da bi se potvrdio smisao koji proistječe iz primjene članka 31, ili da bi se odredio smisao kad je tumačenje prema članku 31:

(a) dvosmisleno ili nejasno; ili

(b) dovodi do ishoda koji je očito besmislen ili nerazuman.

Članak 33 .

Tumačenje ugovora kojih je vjerodostojnost teksta utvrdena na dva ili više jezika

1. Ako je vjerodostojnost teksta ugovora utvrdena na dva ili više jezika, njegov je tekst jednako mjerodavan na svakom od tih jezika, osim ako ugovor odreduje ili se stranke sporazumiju da u slučaju neslaganja prednost ima jedan određeni tekst.

2. Prijevod ugovora na nekom drugom jeziku, osim jezika na kojima je vjerodostojnost teksta utvrdena, smatra se vjerodostojnim tekstom samo ako to ugovor predvida ili ako su se stranke o tome sporazumjele.

3. Smatra se da izrazi u ugovoru imaju isto značenje u svakom vjerodostojnom tekstu.

4. Osim u slućaju kad određeni tekst ima prednost na temelju stavka 1, ako usporedba vjerodostojnih tekstova pokaže razliku u smislu koju primjenom članka 31. i 32. nije moguće otkloniti, usvaja se smisao koji, uzimajuči u obzir predmet i svrhu ugovora, najbolje uskladuje te tekstove. 
naknadu za oduzetu imovinu kad je pitanje te naknade „riješeno međudržavnim sporazumima". ${ }^{41}$ Čini se kako je i ta odredba redakcijski neuređena te donekle nejasna. Na stranu to što se u Zakonu rabi neujednačena terminologija („međunarodni“ ugovori - „međudržavni“ ugovori). Naime, zbog redakcijske neuređenosti nije sasvim izvjesno koji je njen konačni domašaj. ${ }^{42}$ Čini se kako bi bilo logično pretpostaviti da se ne misli da prijašnji vlasnik, u slučaju postojanja međunarodnog ugovora koji uređuje tu materiju, uopće nema pravo na naknadu nego da to pravo nema prema odredbama Zakona o naknadi. Stoga bi se mogao izvući (pogrešan) zaključak kako se ovaj Zakon ne bi mogao primijeniti na osobe koje su unutar polja primjene Ugovora između Svete Stolice i Republike Hrvatske ratione personae.

Naime, u konkretnom slučaju i sam Ugovor između Svete Stolice i Republike Hrvatske u nekim dijelovima upućuje na primjenu „zakonskih odredbi“ (disposizioni legislative). Očigledno je kako se misli na hrvatske pravne propise i to, između ostaloga, u sljedećim slučajevima: a) za utvrđenje pitanja je li moguće izvršiti naturalnu restituciju (članak 2. točka 1.a - koju je moguće vratiti prema zakonskim odredbama; che é possible restituire, secondo le disposizioni legislative), ${ }^{43}$ b) za utvrđivanje prikladne zamjene za dobra koja nije moguće naturalno vratiti (članak 4.) i c) za utvrđivanje novčane naknade za oduzetu imovinu na temelju procjene vrijednosti tih stvari (tih dobara, di tali beni), pri čemu nije potpuno jasno odnose li se riječi „sukladno zakonskim odredbama“ na utvrđivanje novčane naknade ili na sam postupak određivanja (procjene) vrijednosti.

Za donošenje odluke o tome je li neku imovinu moguće naturalno vratiti i kad će ona biti vraćena (u kojem roku) nadležno je mješovito povjerenstvo (članak 3.

41 V. članak 10. Zakona o naknadi 1996.:

„Prijašnji vlasnik nema pravo na naknadu za oduzetu imovinu u slučaju kada je pitanje naknade riješeno međudržavnim sporazumima, ili na drugi način, ako ovim Zakonom nije drukčije propisano."

V. Zakon o izmjenama i dopunama Zakona o naknadi (Narodne novine, 80/2002.) - članak 2.:

Članak 1. mijenja se i glasi:

»Prijašnji vlasnik nema pravo na naknadu za oduzetu imovinu u slučaju kada je pitanje naknade riješeno međudržavnim sporazumima.

Iznimno od odredbe stavka 1. ovoga članka, prava propisana ovim Zakonom mogu steći i strane fizičke i pravne osobe ako se to utvrdi međudržavnim sporazumima." Ispravka navedene novele objavljena je u Narodnim novinama 81/2002. i glasi:

“U članku 2. umjesto riječi: »Članak 1. mijenja se i glasi:« trebaju stajati riječi:»Članak 10. mijenja se i glasi:

42 Odredba je primarno unesena u tekst Zakona kako bi se učinilo nedvojbenim da osobe koje su dobile ili su ovlaštene dobiti naknadu prema međunarodnim ugovorima sklopljenim s Italijom, Sjedinjenim Državama, Mađarskom itd., nemaju pravo na naknadu i prema odredbama Zakona o naknadi.

43 Ova se odredba, zapravo nepotrebno ponavlja u članku 3. stavku 1. Ugovora koji ipak (u hrvatskom izvorniku) sadrži izričitu odredbu da će se hrvatski propisi primjenjivati za donošenje odluke o tome je li moguća naturalna restuticija, usp. tal. le proprietá che é possible restituire, secondo le disposizioni legislative i hrv. „u naravi vratiti imovinu koju je moguće vratiti prema zakonskim propisima“. 
stavak 2. Ugovora), a ne upravno tijelo jedne od ugovornih strana (u konkretnom slučaju Republike Hrvatske), koje je za donošenje takve odluke inače nadležno u drugim slučajevima. Riječi ,sukladno zakonskim odredbama“ ne odnose se na nadležnost tijela za utvrđivanje koja se imovina ne može vratiti (jer je to pitanje jasno uređeno međunarodnim ugovorom), nego na mjerodavno pravo koje treba primijeniti pri utvrđivanju relevantnih činjenica i donošenju odluke o tome može li se neka imovina vratiti ili ne. Stoga su rješenja hrvatskih upravnih tijela koja sadrže utvrđenja o tome je li moguće vratiti imovinu koja je u njima označena donesena od (apsolutno) nenadležnih tijela. Ona su u nekim slučajevima bila nadležna u vrijeme pokretanja postupka (ako je on pokrenut prije stupanja na snagu Ugovora o gospodarskim pitanjima), ali su tijekom njegova trajanja postala nenadležna, pa bi, temeljem članka 25. stavka 2. „staroga“ ZUP-a te predmete trebalo ustupiti mješovitom povjerenstvu. Pravilo o ustaljivanju nadležnosti (perpetuatio fori) iz članka 24. toga Zakona odnosi se samo na mjesnu, a ne na stvarnu i apsolutnu nadležnost. ${ }^{44}$

Dakle, za donošenje odluke o tomu pripada li nekoj pravnoj osobi Katoličke Crkve pravo na povrat imovine nadležno je povjerenstvo iz članka 3. stavka 2. Ugovora. Drugo je pitanje to što je s tom odredbom određeno kako će povjerenstvo odluku donijeti u roku od šest mjeseci nakon njegova stupanja na snagu (,prirediti“ popis). ${ }^{45}$ Budući da je taj rok odavno protekao, postavlja se pitanje ima li ono i dalje nadležnost, tj. može li sačinjavati popis imovine koja će se vratiti i nakon proteka tog roka? Ako bi se ovaj rok smatrao, tzv. instruktivnim rokom, nadležnost mješovitog povjerenstva bi postojala, a svaka od ugovornih strana mogla bi zahtijevati donošenje odgovarajuće odluke. U svezi s ovime treba kazati i sljedeće. Naime, obje ugovorne strane, tacitno ili izričito, već niz godina pristaju na praksu prema kojoj postoji nadležnost hrvatskih upravnih tijela. Sveta Stolica kao ugovorna strana tome se ne protivi (ne protestira), ${ }^{46}$ što bi moglo biti od značaja za tumačenje

44 V. supra bilješke 29. i 30.

45 V. objavu o stupanju na snagu (Narodne novine, 13/2003.).

46 V. Degan, op. cit., str. 202. et seq.:

„Protest (prosvjed, protest, protestation), ima suprotan učinak od priznanja. On sprečava nastanak suprotstavljivoga stanja u odnosu na neki akt ili zahtjev protiv kojega je očitovan, ali samo ako jednostrani akt ili ugovor nije osnovan na općemu međunarodnom pravu. Učinak pravno dopuštenih akata ne može se sprečavati neosnovanim protestima. Obrazložili smo već da protest većega broja država može spriječiti stvaranje novoga običajnoga pravnog pravila, kao i da efektivni protesti jedne države mogu nju izuzeti iz domašaja običajnoga pravila ako ono nastane (supra, §10). Protest isto tako sprečava stvaranje historijskih naslova. Svaki protest prekida rok zastare, iako zastarni rokovi u međunarodnom pravu nisu unaprijed određeni (v. supra, §27, pod (c)). Protest uvijek ima za cilj očuvanje vlastitih prava države koja ga je očitovala. On se može izraziti u pisanom obliku ili usmeno ili konkludentnim činima (v. supra, §10), ali u svakom slučaju mora biti efektivan i u razmjeru s naravi protupravnog djela. No, i kada se smatra da protest nije bio dovoljno efektivan, on ipak sprečava stvaranje suprotstavljivoga stanja u odnosu na državu koja ga je očitovala.“......

„Čak ako pasivnost ne odražava stvarnu namjeru pristanka ili priznanja, od svake se države iz razloga pravne sigurnosti očekuje budnost u zaštiti vlastitih prava i interesa. Iz toga stanja čak proizlazi i osjećaj dužnosti države da protestira u uvjetima koji traže takvu reakciju. 
predmetnoga Ugovora. ${ }^{47}$ Naime, prema uvaženim doktrinarnim stajalištima u takvom bi se slučaju moglo smatrati kako je došlo da nastanka, tzv. ,partikularnog običaja" i faktičke revizije ugovora. ${ }^{48}$

Sljedeće je pitanje kako postupiti, ako mješovito povjerenstvo ne može postići suglasnost? Naime, neovisno o ukupnom broju njegovih članova (2, 4, 6, 8 itd.), a budući da svaka od ugovornih strana ima pravo u sastav mješovitog povjerenstva imenovati jednak broj članova, postoji visok stupanj vjerojatnosti da će članovi iz reda svake od ugovornih strana imati „stajalište“ one ugovorne strane koja ih je imenovala, odnosno glasovati za odluku prema naputcima koje su dobili od svoga vlastodavca, slijedom čega se neće moći postići potrebna većina. ${ }^{49}$ Ako povjerenstvo ne bi moglo prirediti popis imovine koja će biti vraćena (zapravo donijeti odluku

Stoga država koja je zbog nesposobnosti ili neznanja svojih organa nemarna prema svojim vlastitim pravima može snositi teške posljedice svoje neorganiziranosti.“

47 V. članak 31. stavak 3. Bečke konvencije o pravu međunarodnih ugovora u bilješci supra 40. „Zajedno s kontekstom, vodit će se računa:

(a) o svakom naknadnom sporazumu između stranaka o tumačenju ugovora ili o primjeni njegovih odredba;

(b) o svakoj naknadnoj praksi u primjeni ugovora kojom se ustanovljuje sporazum između stranaka o tumačenju ugovora;

(c) o svakom mjerodavnom pravilu međunarodnog prava primjenjivom na odnose između stranaka.“

48 V. Degan, op. cit., str. 108.:

„Naveli smo da, unatoč svim iznesenim ogradama, postoji posebno područje međunarodnoga prava u kojemu partikularni običaj može biti od većega praktičnog značenja. Riječ je o običaju koji nastaje u okviru ugovornog odnosa, a koji smo nazvali „specijalnim” običajem. Države stranke nekoga ugovora mogu u tijeku njegove primjene odstupiti od njegovih propisa, napose ako se taj ugovor primjenjuje tijekom dugog razdoblja, a zbog nekih razloga ne provodi se formalna revizija njegova teksta. Tada se putem običajnih pravila usuglašuje tekst takvoga ugovora $\mathrm{s}$ izmijenjenim socijalnim i političkim uvjetima u kojima se on primjenjuje. Ako je takva praksa stalna, kontinuirana i jednoobrazna između svih stranaka ugovora, ona može dovesti do njihova uvjerenja o obvezatnosti te prakse (opinio juris). Time dolazi do stvaranja partikularnoga običajnog pravila koje ima učinak revizije de facto ugovornog teksta u pitanju.“

49 Svakako bi se u takvom slučaju moglo smatrati da jedna ili obje stranke ne ispunjavaju ugovor u dobroj vjeri. V. Bečku konvenciju:

Članak 26.

Pacta sunt servanda

Svaki ugovor koji je na snazi veže stranke i one ga moraju izvršavati u dobroj vjeri.

Članak 27.

Unutrašnje pravo i poštovanje ugovora

Stranka se ne može pozivati na odredbe svoga unutrašnjeg prava da bi opravdala neizvršavanje ugovora. To pravilo ne dira članak 46.

Članak 46.

Odredbe unutrašnjeg prava o nadležnosti za sklapanje ugovora

1. Država se ne može pozvati na činjenicu da je njezin pristanak da bude vezana ugovorom izražen kršenjem neke odredbe njezina unutrašnjeg prava o nadležnosti za sklapanje ugovora kao na uzrok koji ništi njezin pristanak, osim ako je to kršenje bilo očito i tiče se nekoga bitnog pravila njezina unutrašnjeg prava.

2. Kršenje je očito ako je objektivno jasno svakoj državi koja se glede toga ponaša u skladu s uobičajenom praksom i u dobroj vjeri. 
o tomu glede koje imovine postoji pravo na naknadu), onda bi se zapravo radilo o sporu glede primjene ovog međunarodnog ugovora. Njega ugovorne strane mogu riješiti mirnim putem koji se i predviđa prethodno spomenutim člankom 14. Ugovora, ${ }^{50}$ a mogu se, ako postoji njihova suglasnost u tom pravcu, obratiti i Međunarodnom sudu (International Court of Justice). Međutim, prema dostupnim podatcima Sveta Stolica, odnosno Država Vatikanskog Grada i Republika Hrvatska nisu kod Glavnoga tajnika Ujedinjenih naroda deponirale izjave iz članka 36. stavka 2. Statuta tog Suda, pa je za njegovu nadležnost potrebna posebna suglasnost ovih država. ${ }^{51}$ Dodatno, a budući da Država Vatikanskog Grada nije država članica Ujedinjenih naroda i Statuta Međunarodnog suda, problematika nadležnosti ovoga sudbenog tijela složenija je negoli kad su u pitanju druge države. ${ }^{52}$ Budući da se radi pitanjima koja su izvan dosega ovoga rada - ona se u nastavku neće posebno razmatrati.

50 V. bilješku supra 35.

51 V. članak 36. Statuta:

1. Nadležnost Suda proteže se na sve predmete koje mu podnesu stranke, kao i na sve slučajeve koji su posebno predviđeni u Povelji Ujedinjenih naroda ili u ugovorima i konvencijama koji su na snazi.

2. Države stranke ovoga Statuta mogu u svako doba izjaviti da, prema svakoj drugoj državi koja prihvati istu obvezu, priznaju kao obvezatnu, ipso facto i bez posebnog sporazuma, sudbenost Suda o svim pravnim sporovima što se odnose na:

a) tumačenje nekog ugovora;

b) svako pitanje Međunarodnog prava;

c) postojanje svake činjenice koja bi, ako se ustanovi, tvorila povredu međunarodne obveze;

d) prirodu ili opseg zadovoljenja koje valja dati za povredu međunarodne obveze.

3. Naprijed spomenute izjave mogu se dati bezuvjetno ili uz uvjet uzajamnosti od strane više država ili određenih država, ili za određeno vrijeme.

4. Te se izjave polažu kod glavnog tajnika Ujedinjenih naroda, koji njihov prijepis dostavlja strankama ovoga Statuta i tajniku Suda.

5. Izjave dane prema članku 36. Statuta Stalnog suda međunarodne pravde, koje su još na, snazi, smatraju se među strankama ovoga Statuta prihvatom obvezatne sudbenosti Međunarodnog suda za preostalo vrijeme njihova važenja i u skladu s njihovim odredbama.

6. U slučaju spora o nadležnosti Suda odlučuje sud.

V. i članak 38.:

1. Sud, kojemu je zadaća da njemu podnesene sporove rješava po međunarodnom pravu, primjenjuje:

a) Međunarodne konvencije bilo opće ili posebne, koje ustanovljuju pravila, izrijekom priznata od država u sporu:

b) Međunarodni običaj kao dokaz opće prakse, prihvaćene kao pravo;

c) opća načela prava, priznata od civiliziranih naroda;

d) uz rezervu odredbe članka 59, sudske rješidbe i naučavanja najpozvanijih publicista različitih naroda kao pomoćno sredstvo za utvrđivanje pravih pravila.

2. Ova odredba ne dira u ovlast Suda da odlučuje ex aequo et bono, ako se stranke o tome sporazumiju.

52 V. članak 93. Povelje Ujedinjenih naroda:

1. Svi su Članovi Ujedinjenih naroda ipso facto stranke Statuta Međunarodnog suda.

2. država koja nije Članica Ujedinjenih naroda može postati stranka Statuta Međunarodnog suda uz uvjete koje, za svaki pojedini slučaj, odreduje Opća skupština na preporuku Vijeća sigurnosti. 
Spor između ugovornih strana može se odnositi i na nemogućnost postizanja dogovora iz članka 4. (glede prikladne zamjene za onu imovinu koju nije moguće vratiti u naturalnom obliku i roka ispunjenja te obveze) - također u slučaju da mješovito povjerenstvo iz članka 3. stavka 2. Ugovora ne može donijeti odluku. Dakako, spor se može pojaviti i glede ukupnog iznosa novčane naknade za imovinu koja se neće vratiti ili za koju neće biti dana zamjenska dobra (članak 5. stavak 2.). Što se tiče nadležnosti za donošenje odluke o visini novčane naknade - u Ugovoru se spominje ,crkveno-državno povjerenstvo stručnjaka”. To je povjerenstvo svakako „mješovito“ u smislu da je sastavljeno od predstavnika obje ugovorne strane i pretpostavka je da bi trebalo imati jednak broj članova, imajući u vidu načelo ravnopravnosti stranaka u međunarodnom pravu. Međutim, čini se kako se ne radi o povjerenstvu iz članka 3. stavka $2 .{ }^{53}$

U nastavku će se zanemariti problematika naturalne restitucije. Nedvojbeno je kako bi mješovito povjerenstvo takvu odluku (o mogućnosti naturalne restitucije) trebalo donijeti imajući u vidu hrvatske materijalnopravne propise. Kako je mješovito povjerenstvo nadležno i za donošenje odluke o tomu za koju će se imovinu dati prikladna zamjena (članak 4. Ugovora) te kako se u Ugovoru spominje da će se postupati sukladno ,zakonskim odredbama“, postavlja se pitanje o kojim se „zakonskim odredbama“ radi? Naime, u slučaju nemogućnosti naturalne restitucije, Zakon o naknadi ne sadrži nikakva posebna pravila o tomu kako bi se određivalo što bi bila prikladna ,zamjenska dobra“. ${ }^{54}$ Premda se u konkretnom slučaju ne radi o ugovoru o zamjeni, ${ }^{55}$ mogla bi se imati u vidu pravila hrvatskoga obveznog prava koja se odnose na taj ugovor, kao i opća pravila obveznog prava. ${ }^{56}$ Naime, u

53 V. Ugovori između Svete Stolice i Republike Hrvatske, Hrvatska biskupska konferencija, 2004. str. 303.: "Logično je da isplata naknade za oduzetu imovinu započne 2000. godine, budući je dogovoreno da će crkveno-državno povjerenstvo stručnjaka ustanoviti ukupan iznos naknade koja će se isplaćivati u novcu najkasnije u roku od jedne godine od stupanja na snagu ovoga Ugovora (čl. 5. st. 2.). Ne radi se o mješovitom povjerenstvu spomenutom u člancima 3. i 4. kako to označuje i sam naziv crkveno-državno povjerenstvo stručnjaka. Očito se htjelo naglasiti da će procjenu vrijednosti dobara koja su u pitanju utvrditi stručne osobe. Suvišno je naglasiti da će to povjerenstvo biti sastavljeno od istoga broja crkvenih i državnih stručnjaka."

54 U članku 1. stavku 3. sadrži samo jednu odredbu:

„Ako neka osoba stječe pravo na naknadu određene imovine u naravi, iz razloga obrane ili nacionalne sigurnosti zemlje može joj se dati druga odgovarajuća imovina u vlasništvo ili druga odgovarajuća naknada.“

55 V. Zakon o obveznim odnosima (Narodne novine, 35/05., 41/08., 125/11., 78/15.):

Članak 474.

(1) Ugovorom o zamjeni svaki se ugovaratelj obvezuje prema svom suugovaratelju predati mu stvar u vlasništvo.

(2) Objekt zamjene mogu biti i prenosiva prava.

Članak 475.

Iz ugovora o zamjeni nastaju za svakog ugovaratelja prava i obveze koja iz ugovora o kupoprodaji nastaju za prodavatelja.

56 Ibid., članak 7:

(1) Pri sklapanju naplatnih pravnih poslova sudionici polaze od načela jednake vrijednosti 
konkretnom je slučaju određenom broju pravnih osoba Katoličke Crkve prije više godina prisilno oduzeta imovina i sad ih izvlastitelj (ako bi se taj izraz uopće mogao uporabiti, jer se radi o eufemizmu za radnju koja faktički predstavlja oduzimanje imovine bez naknade, a ne o izvlaštenju), odnosno njegov pravni sljednik, želi staviti u onaj pravni i imovinski položaj kojega su imale prije oduzimanja. U tom se smislu jednakost budućeg položaja s prethodnim može gledati kao jednakost u fizičkom obliku (jednaka površina zemljišta, stana ili neke druge nekretnine, jednaka klasa i/ili kultura zemljišta, jednaka tehnološka opremljenost nekretnine) ili kao jednakost po vrijednosti. Dakako, ugovorne se strane mogu dogovoriti što bi bila ,prikladna zamjena“ (po vrijednosti ili po fizičkom obliku). Ukoliko to nije moguće, opće pravilo obveznog prava upućivalo bi na jednaku vrijednost činidaba.

Ako bi se radilo o želji za postizanjem načela ,jednakovrijednosti“, odnosno da zamjenska dobra imaju jednaku (ili približno jednaku) vrijednost u odnosu na dobra koja su oduzeta, postavlja se pitanje kako bi se odnosne vrijednosti određivale ratione temporis? Bi li se relevantno vremensko razdoblje odnosilo na vrijeme $\mathrm{u}$ kojem se donosi odluka o vraćanju, ili bi trebalo imati u vidu vrijeme u kojem je oduzeta nekretnina koju više nije moguće vratiti? Možda bi u tome mogla pomoći neka druga pravila. Tako, primjerice Zakon o obveznim odnosima ima u vidu vrijednost u vrijeme donošenja odluke suda. ${ }^{57}$ Isto je stajalište bilo zastupljeno i u Zakonu o odgovornosti pravnih osoba za kaznena djela. ${ }^{58}$

Slična problematika javlja se i u slučaju novčane naknade za oduzetu imovinu. Naime, treba li isplatiti naknadu u novčanoj vrijednosti oduzete imovine imajući u vidu vrijednost te imovine u vrijeme oduzimanja ili imajući u vidu njezinu vrijednost u vrijeme donošenja odluke. Neke odredbe ZON-a upućuju na vrijednost imovine u vrijeme oduzimanja, ali se primjenjuju samo u slučaju da je prijašnji vlasnik tijekom razdoblja u kojem je nekretnina bila oduzeta izvršio kakva ulaganja. ${ }^{59}$ Ako

uzajamnih činidaba.

(2) Zakonom se određuje u kojim slučajevima narušavanje toga načela povlači pravne posljedice.

57 V. članak 323.:

„U slučaju ništetnosti ugovora svaka ugovorna strana dužna je vratiti drugoj sve ono što je primila na temelju takva ugovora, a ako to nije moguće, ili ako se narav onoga što je ispunjeno protivi vraćanju, ima se dati odgovarajuća naknada u novcu, prema cijenama u vrijeme donošenja sudske odluke, ako zakon što drugo ne određuje.“

58 Narodne novine, 151/03., 110/07., 45/11., 143/12.

V. članak 20. stavak 4. (ukinut novelom iz 2012.):

„Ako se utvrdi nemogućnost oduzimanja imovinske koristi koja se sastoji od novca, prava ili stvari, sud će obvezati pravnu osobu na isplatu protuvrijednosti u novčanom iznosu. Sud će pri određivanju novčanog iznosa uzeti u obzir tržišnu vrijednost stvari ili prava u vrijeme donošenja odluke."

59 V. članak 49. stavak 2.

„Ako postoji razlika u vrijednosti nekretnine procijenjene u vrijeme donošenja prvostupanjskoga rješenja prema stanju nekretnine kakova bi ona bila u vrijeme oduzimanja, sadašnji vlasnik, odnosno nositelj prava korištenja i raspolaganja može zahtijevati od prijašnjega 
bi se uzimala u obzir vrijednost imovine u vrijeme kad je ona oduzeta, postavilo bi se pitanje kako izjednačiti njenu vrijednost sa sadašnjom vrijednošću? To bi bila gotovo nemoguća zadaća. Ako bi se tako postupilo, onda bi na tako utvrđenu vrijednost trebalo primijeniti ili kakvu indeksnu klauzulu (npr. imajući u vidu cijene nekih roba), ili bi na tako utvrđenu vrijednost trebalo obračunati kamate. Međutim, uzimajući u obzir odredbe ZON-a, a budući da je kamata civilni plod, upitno je bi li se ona mogla obračunavati. ${ }^{60}$

Dakako, ključno je pitanje bi li se opseg naknade za oduzetu imovinu određivao po hrvatskom ili po međunarodnom pravu ${ }^{61}$ Ovo bez obzira na to daje li se u

vlasnika da mu prizna suvlasništvo u omjeru njegovih ulaganja ili da mu isplati odgovarajuću novčanu naknadu u omjeru tih ulaganja u skladu s propisima o stvarnim pravima, odnosno obveznim odnosima. “

60 V. članak 51. stavak 1.:

„Prijašnji vlasnik koji ostvari pravo na naknadu imovine bez obzira u kome obliku, nema pravo na vraćanje plodova, troškova, kao ni pravo na naknadu štete.“

61 V. članak 49.:

Imovina koja je predmet naknade daje se prijašnjem vlasniku prema stanju i načinu korištenja u kojem se nalazi u vrijeme donošenja prvostupanjskoga rješenja o utvrđivanju prava vlasništva, bez obzira na način korištenja u kojem se imovina nalazila u trenutku oduzimanja.

Ako postoji razlika u vrijednosti nekretnine procijenjene u vrijeme donošenja prvostupanjskoga rješenja prema stanju nekretnine kakova bi ona bila u vrijeme oduzimanja, sadašnji vlasnik, odnosno nositelj prava korištenja i raspolaganja može zahtijevati od prijašnjega vlasnika da mu prizna suvlasništvo u omjeru njegovih ulaganja ili da mu isplati odgovarajuću novčanu naknadu u omjeru tih ulaganja u skladu s propisima o stvarnim pravima, odnosno obveznim odnosima.

U slučaju iz stavka 2. ovoga članka, sadašnji vlasnik, odnosno nositelj prava korištenja i raspolaganja nekretnine nije dužan tu nekretninu predati prijašnjem vlasniku u posjed, sve dok mu prijašnji vlasnik ne isplati naknadu za učinjena ulaganja u visini utvrđenoj međusobnim ugovorom ili pravomoćnom sudskom odlukom, ako se drukčije ne sporazume.

Za sporove o kakvom stvarnom pravu ili obvezi koji proisteknu iz rekonstrukcije (adaptacije, nadogradnje, dogradnje, sanacije, izmjene postojećih postrojenja i uređaja i sl.) kao i sporove glede prava na zajedničkim dijelovima zgrade ili zemljišta koji nastanu povodom vraćanja nekretnine prijašnjem vlasniku nadležan je sud, a rokovi protekom kojih se gubi pravo ili rokovi zastare počinju teći od dana stupanja na snagu ovoga Zakona.

Članak 51 .

Prijašnji vlasnik koji ostvari pravo na naknadu imovine bez obzira u kome obliku, nema pravo na vraćanje plodova, troškova, kao ni pravo na naknadu štete.

Prijašnji vlasnik ima pravo na naknadu bez obzira da li je za oduzetu imovinu primio naknadu po ranijim propisima. Moguće primljena naknada ne može se na bilo koji način potraživati od prijašnjeg vlasnika, ako ovim Zakonom nije drukčije propisano.

Prijašnji vlasnik nema pravo na naknadu prema odredbama ovoga Zakona, ako je na ime naknade za oduzetu imovinu primio drugu imovinu ili mu je naknada isplaćena od strane druge države.

Članak 59. 
konkretnom slučaju naknada u novcu ili u stvarima (,prikladna zamjena“). Čini se (prima faciae) kako Ugovor o gospodarskim pitanjima upućuje na to da bi uglavnom trebalo primjenjivati hrvatske materijalnopravne propise (a to bi bili i oni prema kojima se utvrđuje vrijednost oduzete imovine i oblik naknade), dok bi pravila međunarodnog prava trebalo primjenjivati samo utoliko ukoliko hrvatske propise nije moguće primijeniti (jer nisu sukladni odredbama Ugovora - u protivnom bi njegovo sklapanje bilo nepotrebno i besmisleno). To znači da za Katoličku Crkvu i njene pravne osobe ne vrijedi pravilo kako se naknada u pravilu daje u novcu (ili $\mathrm{u}$ vrijednosnim papirima) ${ }^{62}$ - prema Ugovoru o gospodarskim pitanjima pravilo je naturalna restitucija. ${ }^{63}$ Podredno pravilo bilo bi kako ovim osobama pripada pravo na naknadu u obliku zamjenske imovine, ${ }^{64}$ što nije pravilo u drugim slučajevima (osim ako ne postoje kakvi razlozi nacionalne sigurnosti ili obrane zemlje) ${ }^{65}$ te, ako ni to nije moguće, naknada u novcu (što je također dvojbeno imajući u vidu prethodno spomenutu redakcijsku nepreciznost članka 5. stavka 1.), ali ne i u vrijednosnim papirima. Bit eventualnog spora zapravo se i svodi na tumačenje sljedeće odredbe: „Ukupan iznos naknade za oduzetu imovinu, koja će se isplaćivati u novcu, utvrdit će crkveno-državno povjerenstvo stručnjaka na temelju procjene

Visina naknade utvrđuje se prema sljedećim mjerilima:

\begin{tabular}{|c|c|c|c|}
\hline & $\begin{array}{l}\text { VRIJEDNOST } \\
\text { ODUZETE NEKRET- } \\
\text { NINE U KUNAMA } \\
\text { OD - DO }\end{array}$ & $\begin{array}{l}\text { VISINA } \\
\text { NAKNADE U } \\
\text { POSTOCIMA } \\
(\%) \text { OD - DO } \\
\end{array}$ & $\begin{array}{l}\text { IZNOS } \\
\text { NAKNADE } \\
\text { U KUNAMA } \\
\text { OD - DO } \\
\end{array}$ \\
\hline I & $0-100.000$ & $100-73,26$ & $0-73.265$ \\
\hline II & $100.000-1.000 .000$ & $73,26-67,07$ & $73.265-670.696$ \\
\hline III & $1.000 .000-2.000 .000$ & $67,07-61$ & $670.696-1.219 .816$ \\
\hline IV & $2.000 .000-5.000 .000$ & $61-46,78$ & $1.219 .816-2.338 .846$ \\
\hline $\mathbf{V}$ & $5.000 .000-10.000 .000$ & $46,78-31,99$ & 2.338.846 - 3.199.259 \\
\hline VI & $10.000 .000-75.000 .000$ & $31,99-4,93$ & $3.199 .259-3.699 .999$ \\
\hline VII & preko 75.000 .000 & $4,93-0$ & 3.700 .000 \\
\hline
\end{tabular}

Mjerila iz stavka 1. ovoga članka utvrđuju se prema izrazu:

$\mathrm{N}=3.700 .000\left(1-0.9999998^{\mathrm{P}}\right)$

gdje je:

$\mathrm{N}=$ visina naknade $\mathrm{u}$ kunama

$\mathrm{P}=$ vrijednost oduzete imovine $\mathrm{u}$ kunama

62 V. članak 1. stavak 2.:

„Naknada za imovinu oduzetu prijašnjim vlasnicima u smislu ovoga Zakona u načelu je isplata u novcu ili vrijednosnim papirima (dionice ili udjeli i obveznice), a iznimno u naravi.“

63 Članak 3. stavak 1.

"Republika Hrvatska se obvezuje da će Katoličkoj Crkvi, u razumnom roku, vratiti u naravi imovinu koju je moguće vratiti prema zakonskim odredbama."

64 V. članak 4.

65 V. članak 1. stavak $3 .:$

„Ako neka osoba stječe pravo na naknadu određene imovine u naravi, iz razloga obrane ili nacionalne sigurnosti zemlje može joj se dati druga odgovarajuća imovina u vlasništvo ili druga odgovarajuća naknada. 
vrijednosti tih dobara, a u skladu sa zakonskim odredbama, najkasnije u roku od jedne godine od stupanja na snagu ovoga Ugovora." Drugim riječima, sporno je odnosi li se dio ove rečenice koji glasi ,a u skladu sa zakonskim odredbama“ na „procjenu vrijednosti dobara“ ili na to da bi se ,zakonske odredbe“ primjenjivale na iznos naknade za oduzetu imovinu koja uopće ne mora korespondirati s njihovom procijenjenom vrijednošću. ${ }^{66}$

Dakle, ako se naknada daje u obliku ,zamjenske imovine“, radilo bi se o „prikladnoj“ imovini pri čemu je problem utvrditi ,jednakovrijednost“ oduzete imovine i imovine koja se daje u zamjenu. Dodatno, ako se naknada daje u novcu, također je problem utvrditi o kojoj se vrijednosti radi (u vrijeme oduzimanja ili u vrijeme donošenja odluke o vraćanju), kao i donijeti odluku o tome treba li tako utvrđenu vrijednost umanjivati - kao kad su u pitanju drugi ovlaštenici naknade.

Nisu nam dostupni travaux préparatoires glede ovoga Ugovora, što bi moglo biti iznimno značajno za njegovo tumačenje, ali se može pretpostaviti da su ga Sveta Stolica i Republika Hrvatska sklopile upravo zbog toga da Katoličku Crkvu stave u drukčiji položaj u odnosu na druge ovlaštenike prava na naknadu. ${ }^{67}$ Međutim, ostalo je nejasno koliko je taj položaj različit. Naime, nesumnjivo je da je on različit u pogledu općeg načela da se Katolička Crkva ima prvenstveno restituirati u naturalnom obliku, kao i da joj se, ako to nije moguće, trebaju dati zamjenske nekretnine. Ta načela ne vrijede za ostale ovlaštenike ovoga prava. No, je li se riječima „prikladna“ zamjena ili „primjerena“ naknada, također željelo staviti Katoličku Crkvu u drukčiji položaj od drugih ovlaštenika naknade, odnosno da „prikladnost“ ili „primjerenost“ zapravo pretpostavlja jednaku ili barem približnu vrijednost „Zamjenskih“ dobara ili novčanu naknadu koja korespondira s utvrđenom vrijednošću oduzetih nekretnina (i u koje vrijeme), odnosno bez umanjenja koje se odnosi na ostale ovlaštenike prava? Što se tiče prikladne zamjene, drugi ovlaštenici prava na naknadu uopće nemaju pravo na prikladnu zamjenu (osim u prednje navedenim iznimnim slučajevima), ali ostaje sporno odnosi li se „prikladnost“ na stanje i oblik imovine koja se daje u zamjenu ili na njegovu vrijednost? S druge strane, ako se daje novčana naknada ostaje sporno treba li se procijenjena vrijednost umanjiti sukladno zakonskim odredbama ili se „zakonske odredbe“ odnose samo na procjenu? To napose i zbog toga što se u nekim odredbama Ugovora o gospodarskim pitanjima uopće ne spominje ,primjerena“ novčana naknada, niti da ona treba biti „u skladu sa zakonskim odredbama“. ${ }^{68}$

66 V članak 59. u supra bilješci 59.

67 V. Degan, op. cit., str. 141.:

„Članak 32. Bečke konvencije izlaže „dopunska sredstva tumačenja”, kada je tumačenje na temelju „općeg pravila o tumačenju” iz članka 31. dvosmisleno ili nejasno, ili dovodi do ishoda koji je očito besmislen (apsurdan) ili nerazuman, ili čak samo da bi se potvrdio smisao koji proistječe iz članka 31., tj. na temelju tekstualne metode tumačenja. Ta dopunska sredstva uključuju (ali se ne svode na njih): pripremne radove (travaux preparatories) i okolnosti pod kojima je ugovor sklopljen".

68 V. članak 2.:

"U želji da financiranje Katoličke Crkve bude uređeno na suvremen i djelotvoran način, u skladu s demokratskim društvenim ustrojem, Republika Hrvatska se obvezuje da će: 
Ako između ugovornih strana postoji nesuglasje o značenju izraza „prikladna“ zamjena ili „primjerena“ naknada, treba spomenuti da su se one obvezale dogovorom riješiti eventualna sporna pitanja. ${ }^{69}$ Ugovor ne sadrži nikakve procesne odredbe o tome je li taj dogovor obvezatan način rješavanja spora, odnosno procesna pretpostavka za njegovo rješavanje na neki drugi način te koliko dugo dogovaranje treba trajati kako bi se moglo zaključiti da su se pregovori izjalovili. Zabunu unosi i odredba članka 13. stavka 2. prema kojoj bi mješovito povjerenstvo bilo nadležno ,za postizanje dogovora u svezi s primjenom navedenih načela. "70 Budući da je očito kako se ova odredba ne odnosi na odredbu stavka 1. tog članka, jer ona govori o početku primjene Ugovora, treba zaključiti kako bi mješovito povjerenstvo, između ostaloga, bilo nadležno i za postizanje dogovora oko toga koje je značenje izraza „prikladna zamjena“ i/ili ,primjerena naknada“, a ako se u unutar povjerenstva ne postigne dogovor, onda bi to trebale nastojati osobe koje su prema međunarodnom pravu ovlaštene djelovati u ime ugovornih strana u svezi sa sklapanjem međunarodnih ugovora. ${ }^{71}$

Ako izostane dogovor ugovornih strana, tumačenje pojedinih ugovornih odredbi može dati i Međunarodni sud (ICJ), ako stranke pristanu na njegovu nadležnost, pri čemu treba imati u vidu okolnost da jedna od njih nije država članica Ujedinjenih naroda i predstavlja iznimno specifičan subjekt međunarodnog prava. U nastavku će se zanemariti problematika (ne)nadležnosti ovog sudbenog tijela te dati opći pregled međunarodnih izvora prava koje bi ono moglo primjenjivati u konkretnom slučaju, ${ }^{72}$ kao i stajalište autora o tomu koje je moguće tumačenje

1. a) Katoličkoj Crkvi vratiti imovinu koja joj je oduzeta u vrijeme jugoslavenske komunističke vladavine, a koju je moguće vratiti prema zakonskim odredbama.

b) naći odgovarajuću zamjenu za dio dobara, koji nije moguće vratiti;

c) isplaćivati pravnim osobama Katoličke Crkve naknadu u novcu za ostalu imovinu koja neće biti vraćena;

2. priznajući opće društveno vrijedan rad Katoličke Crkve na kulturnom, odgojnom, društvenom i etičkom polju, Katoličkoj Crkvi osiguravati određen godišnji novčani iznos.“

69 V. članak 14. u supra bilješci 35.

70 V. članak 13. u supra bilješci 34.

71 V. članak 7. Bečke konvencije:

„1. Smatra se da neka osoba zastupa državu glede usvajanja ili utvrđivanja vjerodostojnosti teksta ugovora ili glede izražavanja pristanka te države da bude vezana ugovorom:

(a) ako podnese odgovarajuću punomoć, ili

(b) ako iz prakse zainteresiranih država ili iz drugih okolnosti proistječe da su namjeravale smatrati da glede toga ta osoba zastupa državu i da ne zahtijevaju podnošenje punomoći.

2. Na temelju svojih funkcija i bez obveze da podnesu punomoći, smatra se da svoje države zastupaju:

(a) državni glavari, šefovi vlada i ministri vanjskih poslova glede svih čina koji se odnose na sklapanje ugovora:

(b) šefovi diplomatskih misija glede usvajanja teksta ugovora između države koja akreditira i dti,ave u kojoj su akreditirani;

(c) akreditirani predstavnici država na međunarodnoj konferenciji ili u međunarodnoj organizaciji, ili u nekom njezinom organu, glede usvajanja teksta ugovora na toj konferenciji, u toj organizaciji ili u tom organu."

72 V. supra bilješku 51. (članak 38. Statuta). 
pojedinih izraza iz Ugovora o gospodarskim pitanjima između Svete Stolice i Republike Hrvatske. Također će se zanemariti da stranke mogu ovlastiti Međunarodni sud ili neko drugo tijelo da odlučuje po pravičnosti (ex aequo et bono), kao i da načela pravičnosti mogu imati u vidu ako bi se odlučile suglasiti o tumačenju (značenju) spornih odredaba izravnim pregovorima. ${ }^{73}$

Ugovorne strane pri ispunjavanju svojih obveza svakako trebaju postupati sukladno općim pravnim načelima koja se u Statutu Međunarodnog suda pobliže određuju kao ona koja su ,priznata od civiliziranih naroda“, što je prilično dvojbena i zastarjela konstrukcija koja pretpostavlja da postoje „,necivilizirani narodi“ ${ }^{74}$ U konkretnom slučaju bi se moglo nedvojbeno reći kako su vezane, primjerice načelom pacta sund servanda, što znači da slobodno preuzete ugovorne obveze trebaju ispunjavati u dobroj vjeri (bona fides), sukladno načelu zabrane zloporabe prava itd.

Prethodno je navedeno kako se jezičnim tumačenjem pojedinih odredaba Ugovora o gospodarskim pitanjima ne može doći do obostrano zadovoljavajućeg rezultata, kao i da u konkretnom slučaju nisu dostupne isprave i drugi podatci koji se odnose na travaux preparatories, a koji bi mogli biti korisni za izvođenje zaključka o tomu koje su značenje ugovorne strane htjele dati izrazima ,prikladna

73 V. Degan, op. cit., str. 62. et seq.:

„Pravičnost contra legem može se vezivati za posebno ovlaštenje dano od stranaka sudu da njihov spor odluči ex aequo et bono. Pri tome valja naglasiti da sud ne smije nikada otkloniti primjenu pravila pozitivnoga prava ako ono postoji, da bi izbjegao nepravednu odluku, osim ako ga na to obje stranke izričito ne ovlaste. U dosadašnjoj praksi prijeratnoga Stalnoga suda međunarodne pravde i sadašnjega Međunarodnog suda nema ni jedne presude izrečene na temelju stavka 2. članka 38. Statuta Suda. Moguće je ipak i za takve slučajeve utvrditi širinu slobode sudačkog odlučivanja. Ona je mnogo veća od presuđivanja po pravu, ali nije neograničena. Takva vrsta sudačkog odlučivanja najsličnija je izravnim pregovorima stranaka u svrhu zaključenja ugovora. Ako stranke same nisu uspjele sklopiti ugovor, one mogu na sud ili na arbitra prenijeti ovlast da za sporni slučaj svojom presudom propiše novo pravo. No, dok stranke mogu sklopiti nagodbu (transakciju) i na temelju oportunosti, sud i u tim okolnostima mora izreći pravdu, i ne smije se voditi razlozima političke ili druge oportunosti. On mora biti nepristran prema zahtjevima obiju stranaka. Ako je ovlašten da spor presudi ex aequo et bono da bi postigao pravdu, sud može, ali i ne mora, svojom presudom u okviru predmeta spora djelomično ili potpuno izmijeniti stečena subjektivna prava stranaka, ili može vrlo slobodno tumačiti ili čak dokidati njihove međusobne ugovore. Iako se i takvo presuđivanje može makar djelomično ocijeniti kao po pravičnosti contra legem, sud ni tada ne smije činiti ništa što ne smiju ni stranke pri sklapanju ugovora. Presuda ne smije prekoračiti ni jedno imperativno pravilo općega međunarodnog prava (jus cogens), jer bi to i ugovor učinilo ništavim. Ona ne smije zadirati ni u prava trećih država koje nisu stranke spora, jer ga treće države nisu ovlastile presuđivati, a napose ne da odlučuje ex aequo et bono.

Izvan sudačkoga odlučivanja koje se dokončava obvezujućom presudom, a u nedostatku objektivnijih kriterija, pravičnost ima malo značenje kao cilj postizanja nekoga rješenja. Primjerice, u pregovorima o razgraničenju nekoga kopnenog ili morskog prostora svaka od stranaka tvrdit će da je njezin zahtjev pravičan, a da je zahtjev susjedne države nepravičan, neumjeren i nerazuman. Stoga ni kao sredstvo, a ni kao cilj, pravičnost ne može biti zamjena za pravna pravila, niti može biti izvorom međunarodnoga prava.“

74 V. o tome više u Degan, str. 66. et seq. 
zamjena“ ili ,primjerena naknada“. ${ }^{75}$ Međutim, mogle bi se imati u vidu odredbe drugih međunarodnih ugovora (konvencija) u kojima su sadržana pravila o naknadi za oduzetu imovinu (izvlaštenu, nacionaliziranu, konfisciranu), a koja su stranke iz Ugovora o gospodarskim pitanjima izrijekom priznale. Kad je u pitanju Republika Hrvatska, odnosno njezino uobičajeno postupanje prilikom sklapanja međunarodnih ugovora, mogu se spomenuti oni koji tretiraju ovu ili sličnu materiju. Tako, primjerice Ugovor o pitanjima sukcesije sklopljen između država sljednica bivše SFRJ $^{76}$ predviđa obveze ugovornih strana o pružanju zaštite imovinskih interesa pravnih subjekata koji su pripadali toj državi. Ova se zaštita odnosi na njihovu cjelokupnu imovinu i stečena prava. ${ }^{77}$ Posebno se spominju prava koja se odnose na pokretnine ili nekretnine na području država sljednica stečena do 31. prosinca 1990. godine. Naime, postoji obveza da se ova prava priznaju i imovina vrati sukladno „standardima i normama međunarodnog prava“, a ako to nije moguće, da se isplati naknada - opet sukladno ,normama građanskog i međunarodnog prava, " 78 Na ovome mjestu treba istaknuti da pojmovi poput „standardi međunarodnog prava“ ili „norme međunarodnog prava“ nemaju općeprihvaćeno značenje, pa ova odredba nije od velike pomoći ni za rješavanje problematike iz tog Ugovora, kao niti u slučaju

75 Neizravno se ipak može zaključiti da su ugovorne strane prilikom sklapanja Ugovora o gospodarskim pitanjima pod izrazom „sukladno zakonskim odredbama“ imale u vidu Zakon o naknadi. V. Ugovori između Svete Stolice i Republike Hrvatske, op. cit., str. 302.: „To je očito i zato što je u prvim nacrtima Ugovora taj zakon bio izričito spomenut". Što se tiče izraza ,primjerena naknada“, v. str. 303.: „U prvotnom nacrtu ugovora govorilo se o pravednoj naknadi, jer se htjelo naglasiti moralnu obvezu pravedenoga rješenja. Ipak, s pravne točke gledišta sadašnje je kompromisno rješenje ispravnije. Zavisi o dobroj volji dviju strana da primjerena novčana naknada bude i pravedna."

76 Ugovor o pitanjima sukcesije od 29. lipnja 2001. (Narodne novine - Međunarodni ugovori, 2/04.), stupio na snagu 2. lipnja 2004. godine (Narodne novine - Međunarodni ugovori, 5/04.).

77 Ibid., Aneks G, članak 1:.

„Privatna imovina i stečena prava građana i drugih pravnih osoba SFRJ države sljednice štitit će se u skladu s odredbama ovog Aneksa." (Private property and acquired rights of citizens and other legal persons of the SFRY shall be protected by successor States in accordance with the provisions of this Annex.).

78 Ibid., članak 2. stavak 1. točka (a):

„Prava na pokretnu i nepokretnu imovinu koja se nalazi u nekoj državi sljednici na koju su građani ili druge pravne osobe SFRJ imali pravo na dan 31. prosinca 1990. priznat će se, te će biti zaštićena i vraćena od te države u skladu s utvrđenim standardima i normama međunarodnog prava bez obzira na nacionalnost, državljanstvo, mjesto boravka ili prebivalište tih osoba. To uključuje osobe koje su, nakon 31. prosinca 1990. stekle državljanstvo ili mjesto boravka ili prebivalište u nekoj drugoj državi, a ne u državi sljednici. Osobe koje ne mogu ostvariti ova prava imaju pravo na naknadu u skladu s normama građanskog i međunarodnog prava." (The rights to movable and immovable property located in a successor State and to which citizens or other legal persons of the SFRY were entitled on 31 December 1990 shall be recognised, and protected and restored by that State in accordance with established standards and norms of international law and irrespective of the nationality, citizenship, residence or domicile of those persons. This shall include persons who, after 31 December 1990, acquired the citizenship of or established domicile or residence in a State other than a successor State. Persons unable to realize such rights shall be entitled to compensation in accordance with civil and international legal norms.). 
Ugovora o gospodarskim pitanjima. Naime, prilično se često spominje kako je u međunarodnom pravu uobičajeno bez odlaganja isplatiti punu naknadu izvlaštenom subjektu (,,prompt, adequate and effective compensation “, tzv. Hull formula), ${ }^{79}$ ali postoje i drukčija stajališta koja su usvojena i u rezolucijama Ujedinjenih naroda. Prema njima se u slučaju dvojbe ima isplatiti „odgovarajuća“ naknada utvrđena u postupku pred domaćim sudom i primjenom domaćeg prava. Takav je slučaj i s Poveljom o ekonomskim pravima i dužnostima država iz $1974 .{ }^{80}$ Međutim, činjenica je da Hull formula u različitim inačicama, te neovisno o jasno izraženom stajalištu, odnosno protivljenju Opće skupštine Ujedinjenih naroda, prevladava u bilateralnim ugovorima koji uređuju materiju poticanja i zaštite inozemnih ulaganja, pa i onima koje obvezuju Republiku Hrvatsku ${ }^{81}$ Ona je na takvu odredbu pristala i u nekim

79 Takav „standard“, odnosno načela za naknadu izvlaštenim subjektima prvi je spomenuo državni tajnik Sjedinjenih Američkih Država Cordell Hull za vrijeme nacionalizacija imovine američkih naftnih društava u Meksiku 1936. V. OECD Directorate for Financial and Enterprise Affairs, Working Papers on International Investment, 2004/4 „Indirect Expropriation“ and the „Right to Regulate“, u: International Investment Law, str. 2.

80 V. United Nations A/RES/29/3281 Charter of Economic Rights and Duties of States, 1974, Art. 2.2. „Each State has the right: .....c) To nationalize, expropriate or transfer ownership of foreign property, in which case appropriate compensation should be paid by the State adopting such measures, taking into account its relevant laws and regulations and all circumstances that the State considers pertinent. In any case where the question of compensation gives rise to a controversy, it shall be settled under the domestic law of the nationalizing State and by its tribunals, unless it is freely and mutually agreed by all States concerned that other peaceful means be sought on the basis of the sovereign equality of States and in accordance with the principle of free choice of means."

81 Tako primjerice Ugovor o poticanju i zaštiti ulaganja između Litve i Hrvatske (Narodne novine - Međunarodni ugovori, 5/08.) sadrži (u članku 4.):

.....2. Naknada iz točke (c) stavka (1) ovoga članka biti će jednaka tržišnoj vrijednosti izvlaštenog ulaganja neposredno prije nego što je izvlaštenje poduzeto ili je postalo javno poznato, što god je od toga ranije, i bit će isplaćena bez neopravdane odgode. Naknada će uključivati kamatu obračunatu na osnovi LIBOR-a od dana izvlaštenja do dana cjelovite isplate.

Ugovor između Azerbajđana i Hrvatske (Narodne novine - Međunarodni ugovori, 2/08.) članak 6.:

........2. Ta naknada bit će jednaka realnoj tržišnoj vrijednosti izvlaštenog ulaganja neposredno prije nego što je izvlaštenje poduzeto ili je postalo javno poznato,što god je od toga ranije, te će se isplatiti bez neopravdane odgode.

3. Realna tržišna vrijednost iskazat će se u slobodno konvertibilnoj valuti na temelju tržišnog tečaja za tu valutu na dan prijenosa. Naknada će također obuhvatiti kamatu po tržišnoj stopi utvrđenoj na osnovi LIBOR-a za odnosnu valutu od datuma izvlaštenja do datuma stvarnog plaćanja.

Ugovor između Finske i Hrvatske (Narodne novine - Međunarodni ugovori, 11/01.) - članak 5.: ....2. Naknada će biti plaćena bez odlaganja.

3. Takva će naknada biti jednaka stvarnoj tržišnoj vrijednosti izvlaštenog ulaganja neposredno prije nego što je izvlaštenje poduzeto ili je postalo javno poznato, što god je od toga ranije.

4. Stvarna tržišna vrijednost bit će izražena u slobodnoj konvertibilnoj valuti temeljem tržišnog tečaja za tu valutu u vrijeme koje se navodi u stavku 2. ovog članka. Naknada će također uključivati kamatu po komercijalnoj stopi izračunatu na tržišnoj osnovi za tu valutu od dana izvlaštenja do dana stvarnog plaćanja. 
multilateralnim ugovorima, primjerice u Ugovoru o Energetskoj povelji. ${ }^{82} \mathrm{U}$ ovom kontekstu može se spomenuti i članak 1. Protokola 1. uz Europsku konvenciju o zaštiti ljudskih prava i temeljnih sloboda koji, kao ni prethodno spomenuti Ugovor o pitanjima sukcesije bivše SFRJ, ne daje zadovoljavajući odgovor. ${ }^{83}$

Ugovor između Danske i Hrvatske (Narodne novine - Međunarodni ugovori, 14/00.) - članak 4.: ....2. Ta naknada odgovarat će stvarnoj tržišnoj vrijednosti izvlaštenog ulaganja neposredno prije nego se za izvlaštenje ili predstojeće izvlaštenje saznalo na takav način da je to utjecalo na vrijednost ulaganja (u daljnjem tekstu »datum procjene«).

3. Ta stvarna tržišna vrijednost obračunavat će se u slobodno konvertibilnoj valuti na osnovi tržišnog tečaja za tu valutu na dan procjene. Naknada se mora isplatiti pravovremeno i mora uključivati i kamate po komercijalnoj stopi ustanovljenoj na tržišnoj osnovi, od datuma izvlaštenja do datuma isplate.

82 Narodne novine - Međunarodni ugovori, 15/97. (Energy Chater Treaty), v. članak 13.: "1. Investments of investors of a Contracting Party in the area of any other Contracting Party shall not be nationalized, expropriated or subjected to a measure or measures having effect equivalent to nationalization or expropriation (hereinafter referred to as expropriation) except where such expropriation is:

(a) for a purpose which is in the public interest;

(b) not discriminatory;

(c) carried out under due process of law; and

(d) accompanied by the payment of prompt, adequate and effective compensation.

Such compensation shall amount to the fair market value of the investment expropriated at the time immediately before the expropriation or impending expropriation became known in such a way as to affect the value of the investment (hereinafter referred to as the valuation date).

Such fair market value shall at the request of the investor be expressed in a freely convertible currency on the basis of the market rate of exchange existing for that currency on the valuation date. Compensation shall also include interest at a commercial rate established on a market basis from the date of expropriation until the date of payment.

2. The investor affected shall have a right to prompt review, under the law of the Contracting Party making the expropriation, by a judicial or other competent and independent authority of that Contracting Party, of its case, of the valuation of its investment, and of the payment of compensation, in accordance with the principles set out in paragraph 1.

3. For the avoidance of doubt, expropriation shall include situations where a Contracting Party expropriates the assets of a company or enterprise in its area in which an investor of any other Contracting Party has an investment, including through the ownership of shares. ,

83 V. ECHR Article 1. „Protection of Property“:

„Every natural or legal person is entitled to the peaceful enjoyment of his possessions. No one shall be deprived of his possessions except in the public interest and subject to the conditions provided for by law and by the general principles of international law.

The preceding provisions shall not, however, in any way impair the right of a State to enforce such laws as it deems necessary to control the use of property in accordance with the general interest or to secure the payment of taxes or other contributions or penalties.".

Prijevod na hrvatski koji je objavljen u službenom glasilu (Narodne novine - Međunarodni ugovori, 18/97., 6/99. i 8/99.) glasi:

„Članak 1.

\section{ZAŠTITA VLASNIŠTVA}

Svaka fizička ili pravna osoba ima pravo na mirno uživanje svojega vlasništva. Nitko se ne smije lišiti svoga vlasništva, osim u javnom interesu, i to samo uz uvjete predviđene zakonom i općim načelima međunarodnoga prava.

Prethodne odredbe, međutim, ni na koji način ne umanjuju pravo države da primijeni zakone koje smatra potrebnima da bi uredila upotrebu vlasništva u skladu s općim interesom ili za osiguranje plaćanja poreza ili drugih doprinosa ili kazni.“. 
On zapravo predviđa mogućnost primjene domaćeg prava, kao i primjenu općih načela međunarodnog prava, pri čemu u konkretnom slučaju možemo zanemariti problematiku mogućnosti njegove primjene ratione temporis ${ }^{84}$

Iz prednje navedenoga može se zaključiti kako Republika Hrvatska u svojoj praksi sklapanja međunarodnih ugovora uglavnom prihvaća, tzv. Hull formulu, ali i da joj se na načelnoj razini, kao sljednica bivše SFRJ, protivi (u prednje navedenoj Povelji Ujedinjenih naroda o ekonomskim pravima i dužnostima država iz 1974. godine). To nije neuobičajeno, jer je i inače primjetno kako države koje se pri glasovanju za pojedine odluke Ujedinjenih naroda protive Hull formuli, njene bitne odrednice prihvaćaju u brojnim međunarodnim ugovorima. Radi se zapravo o njihovoj faktičkoj neravnopravnosti, želji za privlačenjem stranoga kapitala, ali katkad i nedostatnom znanju i/ili neodgovornosti njihovih dužnosnika. ${ }^{85}$

Ovome treba dodati i sljedeće. Prema Bečkoj konvenciji međunarodni ugovor se mora tumačiti u dobroj vjeri, prema uobičajenom smislu izraza iz ugovora u njihovu kontekstu i u svjetlu predmeta i svrhe ugovora. U tom smislu treba prethodno utvrditi jesu li ugovorne strane u konkretnom slučaju željele dovesti pravne osobe Katoličke Crkve u jednaku ili barem približno jednaku imovinsku situaciju koju su imale prije oduzimanja njihove imovine ili su imale kakvu drugu namjeru. To jezičnim tumačenjem nije moguće utvrditi, a isprave koje se odnose travaux preparatories nisu dostupne. Ako bi se uzela u obzir praksa Republike Hrvatske pri sklapanju drugih međunarodnih ugovora, onda bi mogući zaključak bio da ona pod primjerenom ili prikladnom naknadom u većini slučajeva podrazumijeva „potpunu naknadu“. Međutim, u Ugovoru o gospodarskim pitanjima tako nešto nije izričajem navedeno, zbog čega bi se moglo tvrditi i da bi Republika Hrvatska, ako je imala namjeru Katoličkoj Crkvi dati potpunu naknadu (Hull formula), pristala da se takva izričita odredba unese u Ugovor o gospodarskim pitanjima. U konkretnom slučaju takav je izražaj izostao, pa bi se moglo tvrditi da smisao riječi

Prijevod na hrvatski jezik, kako je to objavljeno u službenom glasilu Republike Hrvatske, je nepravilan. Iz naslova iznad odredbe članka 1. dalo bi se zaključiti da se štiti vlasništvo, a zapravo se štiti imovina (property) koja je daleko širi pojam od vlasništva (osim vlasništva postoje i druga stvarna prava). Iz engleskoga teksta odredbe članka 1. moglo bi se smatrati i da se štiti ostvarivanje posjedovnih prava (peaceful enjoyment of his possessions). U praksi suda se štite sva imovinska prava, pa tako i tražbine, mirovinska prava itd. V. npr. V. Dubenko v. Ukraine ( $\mathrm{N}^{\circ}$ 74221/01) od 11. siječnja 2005., Gizzatova v. Russia ( ${ }^{\circ}$ 5124/03) od 13. siječnja 2005. Poznakhirina v. Russia (Nº 25964/02) od 24. veljače 2005., Stummer v. Austria ( $\left.\mathrm{N}^{\mathrm{o}} 37452 / 02\right)$ od 11. listopada 2007. itd.

$84 \mathrm{U}$ vrijeme donošenja Zakona o naknadi, primjena ECHR-a nije dolazila u obzir ratione temporis, budući da je ona stupila na snagu u odnosu na Republiku Hrvatsku naknadno (5. studenog, 1997. godine). Međutim, njezina bi primjena mogla biti prijeporna glede odluka koje su u svezi s tim Zakonom donesene nakon stupanja Konvencije na snagu.

85 Hull formula prevladava i u praksi međunarodnih sudova i arbitražnih tijela (npr. International Centre for Settletment of Investment Disputes, Iran - United States Claims Tribunal) te odredbama međunarodnih ugovora. Stoga bi značenje riječi ,prikladna zamjena“ ili „primjerena naknada“ trebalo biti što je moguće bliže značenju riječi „(pot)puna naknada“. Dakle, valja držati da se radi o naknadi koja po vrijednosti, a u slučaju zamjenskih dobara i po fizičkim osobinama, najviše odgovara vrijednosti oduzete imovine. 
„primjerena naknada“ ili „prikladna zamjena“ ne uključuje i „potpunu naknadu“. Tako je, primjerice postupio arbitražni sud ICSID (International Centre for Settlement of Investment Disputes) u pravorijeku od 25. siječnja 2000. - Maffezini protiv Kraljevine Španjolske (Arb/97/7). ${ }^{86}$ Stajališta smo da su ipak uvjerljiviji argumenti u prilog potpunoj naknadi, već i zbog toga što odredba članka 5. stavka 3. Ugovora o gospodarskim pitanjima implicira kako bi naknada trebala odgovarati vrijednosti oduzete imovine. Naime, s njom se predviđa da će se primljeni novčani iznosi raspoređivati na pojedine pravne osobe Katoličke Crkve sukladno vrijednosti oduzete imovine

86 V. Kunštek, Procedural Effects of the BITs Most Favoured Nation Clauses on ICSID Arbitration, Croatian Arbitration Yearbook 15, 2008.

Relevantni dio pravorijeka na španjolskom jeziku glasi:

„... El Tribunal también ha examinado en detalle la práctica que ha seguido España en cuanto a los tratados bilaterales de inversión con otros países. ...... El Tribunal observa asimismo que de todos los tratados españoles que ha podido examinar, el único que se refiere a "todas las materias regidas por el presente Acuerdo" en lo que respecta a la cláusula de la nación más favorecida es el suscrito con Argentina. Todos los demás tratados, incluidos los suscritos con Uruguay y Chile, omiten esta referencia y solamente disponen que "este tratamiento" estará sujeto a la cláusula, que es naturalmente una formulación más restrictiva.“ 
Summary

\section{CERTAIN DOUBTS REGARDING THE IMPLEMENTATION OF THE LAW ON COMPENSATION FOR PROPERTY TAKEN DURING THE YUGOSLAV COMMUNIST REGIME}

\section{- legal nature of time limit for instituting proceedings/relationship to the Treaty on Economic Issues between the Republic of Croatia and the Holy See -}

This paper focuses on some of the problems that have arisen in the implementation of the Law on Compensation for Property Taken during the Yugoslav Communist Regime and the Treaty on Economic Issues concluded between the Republic of Croatia and the Holy See. It appears that the dispute about the legal nature of time limit for instituting proceedings according to the latter and other laws has been resolved by the decision of the Constitutional Court in case no. U-III-5694/13 of March 1 $1^{\text {st }}, 2016$, at least insofar as judicature is concerned. On the other hand, the application of the above mentioned legal act and its relation to the Treaty with the Holy See raises certain doubts. This paper presents and analyses opposing arguments for alternative conclusions on the most important issues within the scope of the above acts' application - which are equally legitimate and persuasive. Concluding, the authors recommend that the parties to the present Treaty and/or mixed commission use their powers in order to regulate the rights and duties of the Holy See and the Republic of Croatia in a clear and unambiguous manner.

Keywords: compensation for taken property, time limit for instituting proceedings, the Holy See. 
Zusammenfassung

\section{ZU ZWEIFELN IN DER ANWENDUNG DES GESETZES ÜBER SCHADENSAUSGLEICH FÜR WÄHREND DES JUGOSLAWISCHEN KOMMUNISTISCHEN REGIMES WEGGENOMMENES VERMÖGEN}

\section{- Die Rechtsnatur der Frist für Einleitung des Verfahrens und Beziehung zum Vertrag zwischen dem Heilgen Stuhl und der Republik Kroatien über wirtschaftliche Fragen -}

Die vorliegende Arbeit beschäftigt sich mit einigen Probleme in der Anwendung des Gesetzes über Schadensausgleich für während des jugoslawischen kommunistischen Regimes weggenommenes Vermögen und des Vertrages zwischen dem Heiligen Stuhl und Republik Kroatien über wirtschaftliche Fragen. Die Streitigkeit um die Rechtsnatur der Frist für die Einleitung des Verfahrens gemäß den genannten Gesetzen scheint jedoch durch die Entscheidung des Verfassungsgerichts Nr: U-III-5694/13 vom 1. März 2016 gelöst zu sein. Im Gegensatz dazu bestehen auch weiterhin Zweifel hinsichtlich der Anwendung dieses Gesetzes, sowie seiner Beziehung zum Vertrag mit dem Heiligen Stuhl. Die Autoren stellen und analysieren entgegengesetzte Argumente dar - die gleichermaßen legitim und überzeugend sind - und die zur unterschiedlichen Schlussfolgerungen über die wichtigsten Fragen zur Anwendung der genannten Gesetze führen. Zum Schluss wird vorgeschlagen, dass die Vertragsparteien und/oder gemischte Kommission ihre Vertragsbefugnisse dazu ausnutzen um die Verhältnisse zwischen dem Heiligen Stuhl und Republik Kroatien klar und eindeutig zu regeln.

Schlüsselwörter: Schadensausgleich für weggenommenes Vermögen, Frist für Einleitung des Verfahrens, der Heilige Stuhl. 


\section{Riassunto}

\section{ALCUNI DUBBI CIRCA L'APPLICAZIONE DELLA LEGGE SULL'INDENNIZZO PER IL PATRIMONIO SOTTRATTO AL TEMPO DEL REGIME COMUNISTA JUGOSLAVO}

\section{- Natura giuridica del termine per l'avvio del procedimento - - Rapporto nei confronti dell'Accordo della Repubblica di Croazia e della Santa Sede sulle questioni economiche -}

Nel lavoro di analizza parte delle questioni sorte in ragione dell'applicazione della Legge sull'indennizzo per il patrimonio sottratto durante il regime comunista jugoslavo e dell'Accordo sulle questioni economiche stipulato tra la Repubblica di Croazia e la Santa Sede. Pare che la diatriba circa la natura giuridica del termine per l'avvio del procedimento in forza di tale e di altre leggi, perlomeno nella giudicatura, sia stata risolta con la decisione della Corte costituzionale nel caso U-III-5694/13 del 1 marzo 2016. Non si può affermare, invece, altrettanto per i dubbi che esistono riguardo all'applicazione di tale legge ed il suo rapporto nei confronti dell'Accordo con la Santa Sede. Nel lavoro vengono esposti ed analizzati argomenti contrapposti forieri di orientamenti diversi riguardo le questioni più importanti all'interno del campo di applicazione di tali disposizioni normative, i quali sono egualmente giustificati e convincenti. Pertanto gli autori suggeriscono che le parti contrattuali e/o una commissione mista di tale Accordo utilizzino i propri poteri e regolino i rapporti tra la Santa Sede e la Repubblica di Croazia in maniera chiara ed univoca.

Parole chiave: indennizzo per il patrimonio sottratto, termine per l'avvio del procedimento, Santa Sede. 